Running title: Sugar beet raffinose metabolism

\title{
Cold-triggered induction of ROS- and raffinose-related metabolism in freezing-sensitive taproot tissue of sugar beet
}

Isabel Keller ${ }^{1}$, Christina Müdsam², Cristina Martins Rodrigues' ${ }^{1}$, Dominik Kischka², Wolfgang Zierer², Uwe Sonnewald ${ }^{2}$, Karsten Harms ${ }^{3}$, Olaf Czarnecki ${ }^{4}$, Karin Fiedler-Wiechers ${ }^{4}$, Wolfgang Koch ${ }^{4}, \mathrm{H}$. Ekkehard Neuhaus ${ }^{1}$, Frank Ludewig ${ }^{4}$, Benjamin Pommerrenig ${ }^{1^{*}}$

Corresponding Author:

Dr. Benjamin Pommerrenig

Plant Physiology

University of Kaiserslautern

Paul-Ehrlich-Str 22

67663 Kaiserslautern

Germany

Phone: +49 (0) 6312052894

E-Mail: pommerre@bio.uni-kl.de

1Department of Plant Physiology, University of Kaiserslautern, Paul-Ehrlich-Str.22, 67663

Kaiserslautern, Germany

2Department of Biochemistry, FAU Erlangen-Nürnberg, Staudtstr. 5, 91052 Erlangen, Germany

3 Südzucker AG, CRDS, Wormser Str. 11, 67283 Obrigheim/Pfalz, Germany

${ }^{4}$ KWS SAAT SE \& Co. KGaA, Grimsehlstraße 31, 37574 Einbeck, Germany

Short title: Sugar beet raffinose metabolism

Funding: This work was supported by a research grant to H.E.N and U.S. by the Federal Ministry of Education and Research (BMBF project Betahiemis, FKZ 031B0185) and a PhD grant from KWS SAAT SE \& Co. KGaA to I.K. ("Understanding of frost tolerance and frost resistance of meristematic tissues of sugar beet (Beta vulgaris) taproots"). 


\section{Abstract}

2 Sugar beet (Beta vulgaris subsp. vulgaris) is the exclusive source of sugar in the form of sucrose in

3 temperate climate zones. There, sugar beet is grown as an annual crop from spring to autumn because

4 of the damaging effect of freezing temperatures to taproot tissue. Natural and breeded varieties

5 display variance in the degree of tolerance to freezing temperatures and genotypes with elevated

6 tolerance to freezing have been isolated. Here we compare initial responses to frost between

7 genotypes with either low and high winter survival rates. The selected genotypes differed in the

8 severity of frost injury. We combined transcriptomic and metabolite analyses of leaf- and taproot

9 tissues from such genotypes to elucidate mechanisms of the early freezing response and to dissect

10 genotype- and tissue-dependent responses. Freezing temperatures induced drastic downregulation

11 of photosynthesis-related genes in leaves but upregulation of genes related to minor carbohydrate

12 metabolism, particularly of genes involved in raffinose metabolism in both, leaf and taproot tissue. In

13 agreement with this, it has been revealed that raffinose and the corresponding intermediates, inositol

14 and galactinol, increased markedly in these tissues. We found that genotypes with improved tolerance

15 to freezing, showed higher accumulation of raffinose in a defined interior region within the upper

16 part of the taproot, the pith, representing the tissue most susceptible to freeze damages. This

17 accumulation was accompanied by specific upregulation of raffinose synthesizing enzymes in

18 taproots, suggesting a protective role for raffinose and its precursors for freezing damage in sugar

19 beet. 


\section{INTRODUCTION}

23 In temperate climate zones (Europe and North America), sugar beet (Beta vulgaris subsp. vulgaris) is

24 the exclusive source of sugar (sucrose) for the food industry and a source for bio-energy generation.

25 Sugar beet taproots are able to accumulate sucrose to up to nearly $20 \%$ of their fresh weight at 26 maturity (Dohm et al., 2013) and provide about 30\% of the total sugar produced worldwide (Y.-F.

27 Zhang et al., 2017). Owing to its biennial lifestyle, the plant forms the huge sucrose-storing taproot 28 during the first year of its life cycle. The stored sugar is used to fuel the outgrowth of a flowering seed

29 stalk in the reproductive phase in the second year of growth (Chen et al., 2016). Induction of

30 flowering, however, requires a prolonged exposure to cold (between 5-20 weeks at $4-15^{\circ} \mathrm{C}$ ), known

31 as vernalization (Abo-Elwafa et al., 2006; Kockelmann et al., 2010). During vernalization, shoots and

32 taproots prepare for metabolic and functional rearrangements resulting in a switch of their source

33 and sink identities, where shoot metabolism depends on carbon supply from the taproot to allow

34 outgrowth of the seed stalk (Rodrigues et al., 2020). Successful vernalization of sugar beet plants can

35 only occur at low, but above-zero temperatures. This is because, despite the high accumulation of

36 sugars, which are known to stabilize membranes and protect against freezing-induced damages

37 (Anchordoguy et al., 1987; Pommerrenig et al., 2018), sugar beet is sensitive to subzero temperatures

38 (Barbier et al., 1982; Loel and Hoffmann, 2015). This sensitivity allows cultivation of the crop in its

39 production area only in a limited vegetation period from spring to late autumn. The limited growth

40 period and the slow formation of leaves in spring are its main yield limiting factors (Jaggard et al.,

41 2009; Milford and Riley, 1980). Calculations taking an increased freezing and bolting tolerance into

42 account suggested that an elongated growth period of sugar beet might result in an increase of the

43 total sugar yield by about 25\% (Hoffmann and Kluge-Severin, 2011). However, overwintering sugar

44 beet plants must be able to withstand freezing temperatures, and therefore, freezing tolerance has

45 become a desirable trait for sugar beet breeders. Freezing temperatures frequently lead to severe 46 yield losses of different crops (Barbier et al., 1982; Chang et al., 2014; Fennell, 2004; Maqbool et al., 
47 2010), as intra- and extracellular ice formation damages plant tissue by rupturing cell membranes or

48 because of cellular dehydration (Burke et al., 1976; Wolfe and Bryant, 1999). On the macroscopic

49 level, the impact of freezing on sugar beet taproot tissue is drastic and results in lethal damage to

50 internal tissue and ultimately, the entire plant. Ice formation and thawing leads to cell rupture and

51 leakage of root sap, which ultimately attracts microorganisms and leads to rot of the taproot body

52 (Barbier et al., 1982).

53 Factors protecting plants against freezing may be soluble sugars, amino acids, organic acids, or

54 derivatives thereof, which function as osmolytes and can thus lower the freezing point, or prevent

55 cellular dehydration upon freezing. Additionally, some of these metabolites can stabilize enzymes,

56 membranes and other cellular components (Guy, 1990; Yadav, 2010). In particular, small

57 carbohydrates like fructans or raffinose family oligosaccharides (RFOs) have superior membrane

58 protective abilities and additionally represent potent quenchers of reactive oxygen species (ROS) (De

59 Roover et al., 2000; Hincha et al., 2007; Pontis, 1989). Accumulation of high levels of fructans in plants

60 of the Asteraceae familiy like chicory (Cichorium intybus) or Jerusalem artichoke (Helianthus

61 tuberosus), for example, render these species highly tolerant against freezing damage. Sugar beet does

62 not produce fructans but can form considerable amounts of raffinose, which are derived from sucrose,

63 especially during storage of taproots (Haagenson et al., 2008; Wyse and Dexter, 1971). However,

64 raffinose biosynthesis is attended by reduction of sucrose levels. In fact, as part of the so-called

65 molasses, raffinose is considered an unwanted contaminant lowering the maximum amount of

66 sucrose extractable from the pulp during industrial processing (Ganter et al., 1988; Wyse and Dexter,

67 1971). On the other hand, raffinose is important for plant frost tolerance (Nishizawa et al., 2008;

68 Pennycooke et al., 2003; Peters and Keller, 2009). Raffinose is a trisaccharide consisting of sucrose

69 and galactose and is synthesized via a subsequent transfer of activated galactose moieties, donated

70 by galactinol, to sucrose (Sengupta et al., 2015). Two specific enzymes, galactinol synthase (GOLS)

71 and raffinose synthase (RS), mediate the synthesis of galactinol and raffinose, respectively. GOLS 
72 mediates the first metabolic step in raffinose biosynthesis, the conversion of UDP-Galactose and myo-

73 inositol to galactinol. Raffinose biosynthesis is specifically upregulated during cold acclimation

74 processes, and several galactinol synthase genes (GOLS) are transcriptionally regulated in Arabidopsis

75 thaliana via low temperature response transcription factors of the C- repeat binding factor (CBF)

76 family (Fowler and Thomashow, 2002; Gilmour et al., 2000; Taji et al., 2002). CBF proteins directly

77 regulate cold-responsive (COR) genes, which facilitate the acquisition of cold acclimation and

78 sustained freezing tolerance, as products of COR genes are involved in processes like the synthesis of

79 osmo-protectants and also raffinose, lipid metabolism or cell wall modification (Liu et al., 2019;

80 Thomashow, 1999). In sugar beet, CBFs like CBF3, were shown to be upregulated early upon cold and

81 freezing temperatures, but were only detected in roots so far (Moliterni et al., 2015).

82 In this work, we analyzed how low temperatures would influence the accumulation of diverse sugar

83 and RFO species in different sugar beet tissues and genotypes. In addition, we present detailed

84 information on raffinose- and inositol-related gene expression and substrate contents in different

85 organs and tissues of sugar beets, exposed to control and freezing temperatures. Our analysis

86 indicates that inositol and raffinose biosynthesis are spatially regulated in a low temperature-

87 dependent manner. We discuss whether these compounds could serve as indicators for the cold and

88 freezing stress level, or whether they may play a direct role in freeze-protection. The identified frost

89 protective substances represent possible targets for screening, breeding or genetic modification of

90 sugar beet varieties with increased winter hardiness and frost tolerance.

\section{RESULTS}

\section{Sugar beet genotypes respond differently to freezing temperatures}

93 Sub-zero temperatures have a detrimental effect on sugar beet tissue resulting in a structural collapse

94 of the affected cells leading to sucrose leakage out of vacuoles and eventual rotting of taproot tissue 
95 (Barbier et al., 1982). To learn about physiological and molecular responses that might mitigate

96 harmful effects of freezing temperatures, we analyzed three genotypes (GT1, GT2, GT3) with different

97 freezing sensitivities from a panel of accessions that was tested for survival of freezing temperatures

98 in field or greenhouse trials. In these tests, GT1 had low survival rates (SR) (14\% in field and 11\% in

99 greenhouse trials), GT2 high SR (90\% in field and 66\% in greenhouse trials), and GT3 intermediate

100 SR (77\% in field and 56\% in greenhouse trials). These rates categorized GT1 as freezing sensitive,

101 GT2 as freezing tolerant, and GT3 as moderately freezing tolerant (Fig. 1A). For the experiments

102 presented in this paper, we grew the three different genotypes under a fixed temperature profile in

103 climate-controlled growth chambers and monitored their behavior in respect to the set temperature

104 (Fig. 1B). Freezing stress was applied until the temperature, measured $5 \mathrm{~cm}$ below the surface of the

105 potting soil, was decreased to $0^{\circ} \mathrm{C}$ (approximately 3 days). After frost exposure, plants were

106 transferred to $20^{\circ} \mathrm{C}$ for recovery. The severity of injuries by the three genotypes following treatment

107 indeed mirrored their survival rates from the prior field and greenhouse trials. For instance, most of

108 GT1 shoots collapsed during cold exposure and a comparably high number of GT1 plants did not

109 recover and died after the freezing treatment (Fig. 1C). Importantly, initial exposure to freezing

110 temperature did not kill plants, but severely affected their performance during recovery at higher

111 temperatures in a genotype-dependent manner (Fig. 1C). Photosynthesis, measured as effective

112 quantum yield of photosystem II $\left(\Phi_{\mathrm{II}}\right)$, significantly declined at $0^{\circ} \mathrm{C}$ in all three genotypes, but

113 strongest in freezing-sensitive GT1 plants (Fig. 1D). In contrast, plants from the more freezing-

114 tolerant GT2 and GT3 genotypes were able to increase $\Phi_{\text {II }}$ to pre-freezing levels after retransfer to

$11512^{\circ} \mathrm{C}$ (Fig. 1D). Consistently, GT1 plants showed higher non-photochemical quenching (NPQ) in

116 comparison to GT2 and GT3 plants during and after exposure to frost (Fig. 1D).

117 Following treatment, a large number of roots from GT1 plants, displayed visible brownish rot in a

118 defined region within the taproot neck, designated as pith (Fig. 1E). With progression of the rotting,

119 affected taproots lost structural integrity and plants died. The pith tissues of the two more tolerant 
120 cultivars, GT2 and GT3, were not affected to the same extent. Such changes, as observed above, can

121 be evoked by reactive oxygen species (ROS). To check whether the low temperature exposure was

122 associated with formation of ROS, we performed staining of taproot slices with diaminobenzidine

123 (DAB) and nitroblue tetrazolium (NBT) to reveal accumulation of $\mathrm{H}_{2} \mathrm{O}_{2}$ and superoxide, respectively.

124 Staining was most intense during or after freezing treatment and DAB-derived dark brown or NBT-

125 derived blue staining indicated that both types of reactive oxygen species strongly accumulated in the

126 vasculature and in the pith of taproots (Fig. 1F and Supplemental Fig. S1A). Overall, our

127 observations revealed that frost induced tissue damage, as well as emergence of ROS are clustered in

128 the upper part of the sugar beet taproot, mainly in the pith tissue. 
bioRxiv preprint doi: https://doi.org/10.1101/2021.04.12.439442; this version posted April 13, 2021. The copyright holder for this preprint (which was not certified by peer review) is the author/funder, who has granted bioRxiv a license to display the preprint in perpetuity. It is made available under ACC-BY-NC-ND 4.0 International license.

A

\begin{tabular}{ccc}
\hline $\begin{array}{c}\text { Geno- } \\
\text { type }\end{array}$ & SR field & $\begin{array}{c}\text { SR growth } \\
\text { chamber }\end{array}$ \\
\hline GT1 & $14 \%$ & $11 \%$ \\
GT2 & $90 \%$ & $66 \%$ \\
GT3 & $77 \%$ & $56 \%$ \\
\hline
\end{tabular}

C

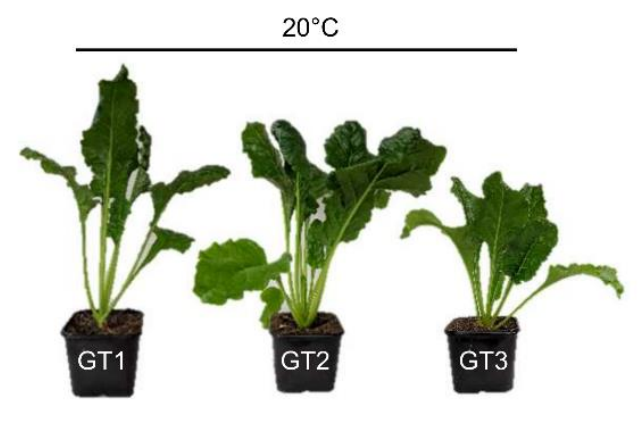

B

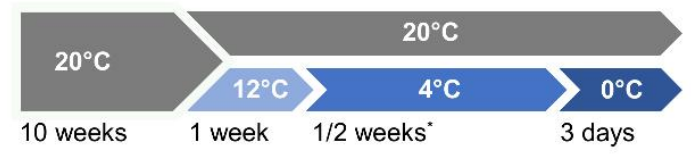

D
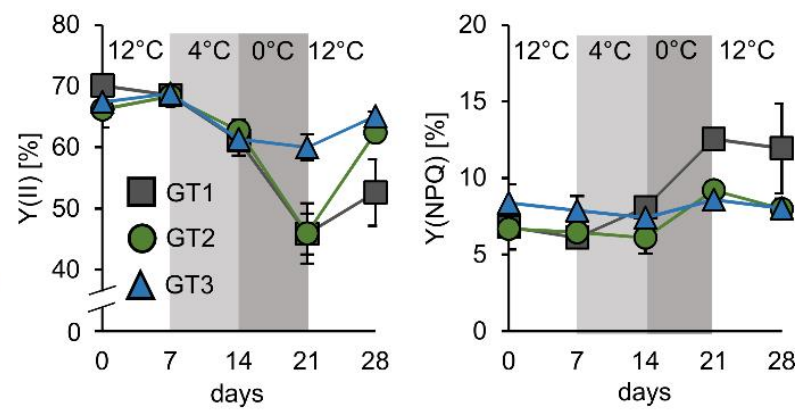

E

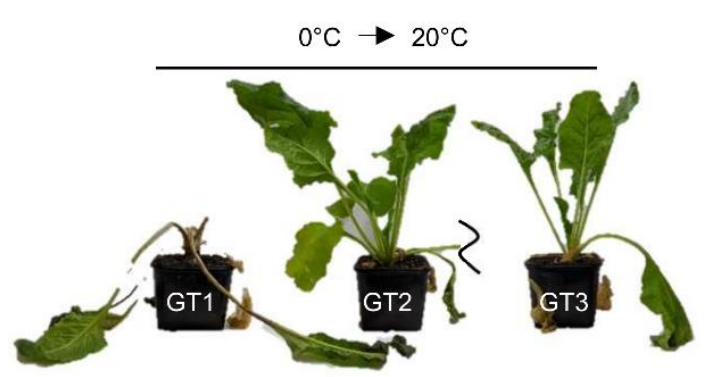

F

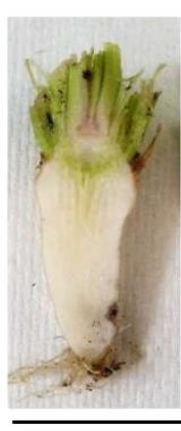

$20^{\circ} \mathrm{C}$

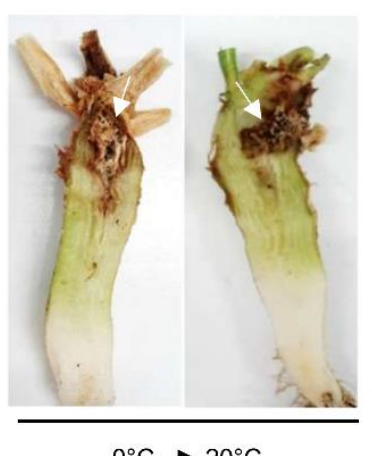

$0^{\circ} \mathrm{C} \rightarrow 20^{\circ} \mathrm{C}$

$20^{\circ} \mathrm{C}$
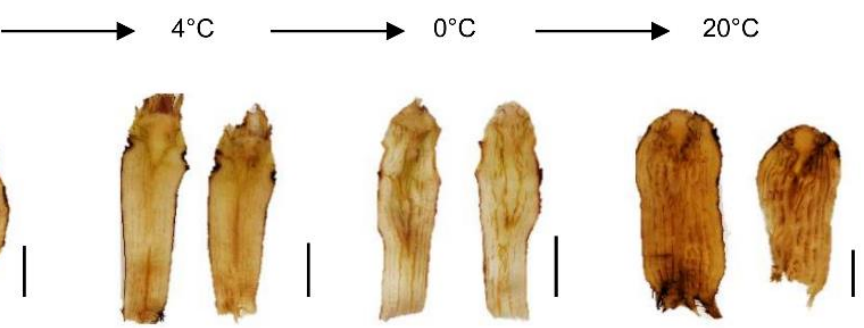

GT2
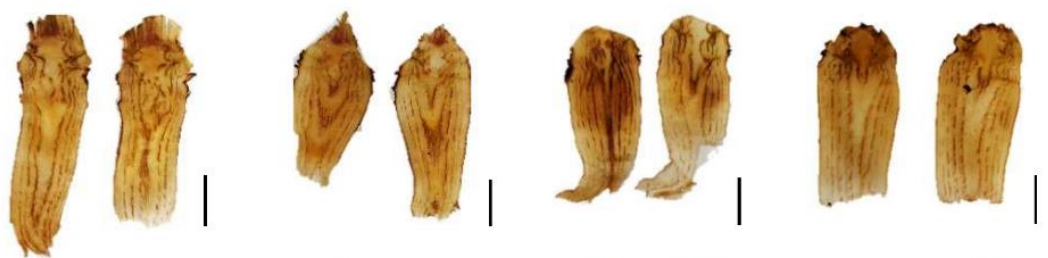

GT3
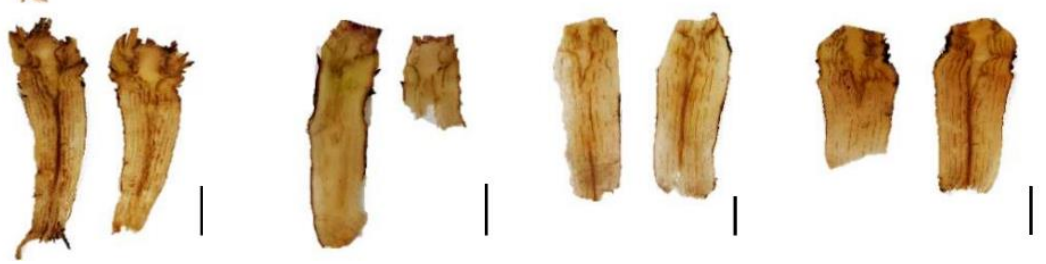
134 Figure 1: Responses of sugar beet genotypes to freezing temperatures. (A) Freezing survival rates (SR) of 135 three analyzed sugar beet cultivars GT1, GT2 and GT3 measured under field and growth chamber conditions 136 given in percent of survived plants. (B) Experimental setup for metabolite and photosynthesis measurements. 137 Plants were grown at $20^{\circ} \mathrm{C}$ for 10 weeks. Subsequently, plants were kept at $20^{\circ} \mathrm{C}$ (control) or transferred to low 138 temperature acclimation conditions $\left(12^{\circ} \mathrm{C}\right.$ for one week, and $4^{\circ} \mathrm{C}$ one week for photosynthesis measurements, 139 two weeks for RNASeq and metabolite analysis). After $4^{\circ} \mathrm{C}$ treatment, air temperature in the growth chamber 140 was lowered to $-6^{\circ} \mathrm{C}$ and plants were harvested as soon as the soil temperature was $0^{\circ} \mathrm{C}$ or below, which was 141 the case three days after transfer to $-6^{\circ} \mathrm{C}$. (C) Typical appearance of sugar beet plants of GT1, GT2 and GT3 142 before and after freezing treatment. (D) PAM measurements were performed on leaves of the three different 143 genotypes. For this, air temperature was kept at $0^{\circ} \mathrm{C}$. Quantum yield of photosynthesis [Y(II)] and non144 photochemical quenching [Y(NPQ)] were measured. Temperature intervals are highlighted in white $\left(12^{\circ} \mathrm{C}\right)$, 145 light grey $\left(4^{\circ} \mathrm{C}\right)$, or grey $\left(0^{\circ} \mathrm{C}\right)$. Values represent the mean of three biological replicates. Error bars represent the 146 standard error of the corresponding mean. Significant changes relative to the control condition $\left(20^{\circ} \mathrm{C}\right)$ were 147 calculated independently for each genotype using Student's $t$-test $\left(* \mathrm{p}<0.05 ;{ }^{* *} \mathrm{p}<0.01 ;{ }^{* * *} \mathrm{p}<0.001\right)$. (E) 148 Morphology of sugar beet taproots of genotype GT1 after freezing recovery. Plants were grown at $20^{\circ} \mathrm{C}$ for 13 149 weeks and afterwards were shifted to $12^{\circ} \mathrm{C}, 4^{\circ} \mathrm{C}$ and $0^{\circ} \mathrm{C}$ and were retransferred to $20^{\circ} \mathrm{C}$ after freezing 150 treatment. (F) DAB staining indicative for hydrogen peroxide accumulation in longitudinal sections of 10-week 151 old taproots. Scale bars represent $1 \mathrm{~cm}$.

153 The sugar beet taproot is divided into two distinct tissue zones with different sensitivities to 154 freezing

155 Almost a century ago, plant anatomist Ernst Artschwager noted the anatomic peculiarities of the pith 156 tissue (Artschwager, 1926). Its anatomy differs from other internal taproot tissues, which mainly 157 comprise the storage parenchyma (SP) and vascular tissue (Fig. 2A). Our microscopic analysis 158 confirmed Artschwager's observation that the pith consists of spongiform parenchyma cells and 159 revealed that pith cells are more than five times the size of parenchymatic cells alternating with 160 xylem/phloem bundles in the distal parts of the beets (i.e. between the characteristic concentric rings 161 that can be observed in transverse sections, mainly through the below-pith beet tissue) (Fig. 2B-D). 162 While the storage parenchyma was drawn with vascular bundles, such long-distance transport tissue 163 was absent from the pith, which was surrounded mostly by primary xylem (Fig. 2C and 2E). The 
164 primary xylem in turn could be traced acropetally towards the vasculature of the oldest leaves and

165 cotyledons, and basipetally to where some of the bundles converge in the central cylinder in below-

166 pith root tissue (Fig. 2F). Application of the phloem-mobile carboxyfluoresceine di-acetate (CFDA) to

167 source leaves and subsequent tracking of its green-fluorescent derivative CF in the taproot via

168 confocal microscopy confirmed the occurrence of vascular bundles in storage parenchyma and,

169 importantly, their absence from the pith region (Fig. 2E and 2F). To record differential responses in

170 gene expression and metabolite accumulation in SP and pith, we manually separated both tissues.

171 Because of the proximity of the pith to the shoot apical meristem (SAM) (Fig. 2A) and with a lack of

172 known markers for the pith, we checked for accumulation of the mRNA of the SAM-marker CLAVATA2

173 as indicator for successful enrichment of pith tissue (Fig. 2G). To check whether SP and pith tissue

174 are able to precipitate cold- and freezing treatment under our test conditions, expression of the low

175 temperature response transcription factor $C B F 3$ was analyzed (Fig. 2H). Expression of $C B F 3$ did not

176 differ between the three analyzed genotypes, but was significantly higher in the pith in comparison

177 to storage parenchyma at $0^{\circ} \mathrm{C}$, underlining the marked cold susceptibility of this special tissue (Fig.

178 2H). 
A

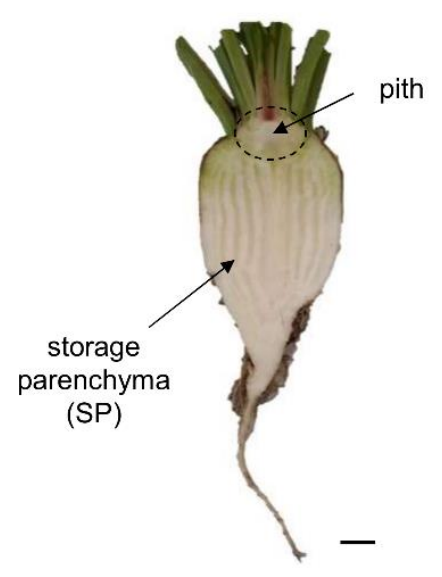

D

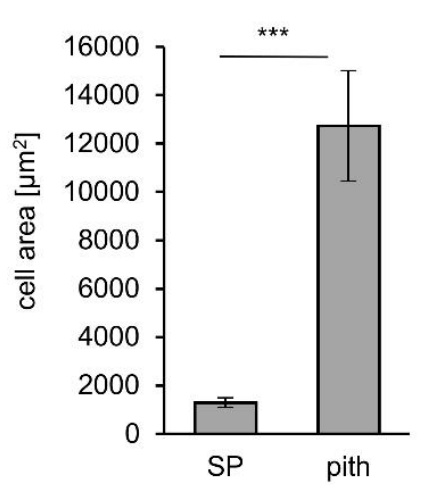

G

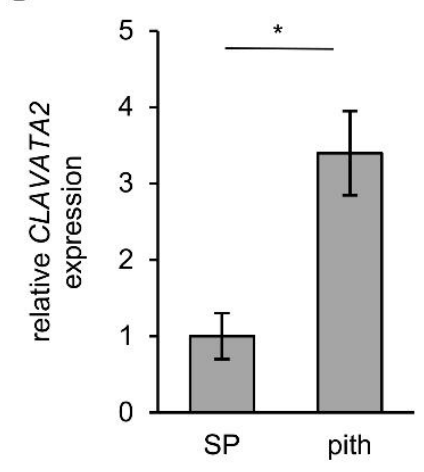

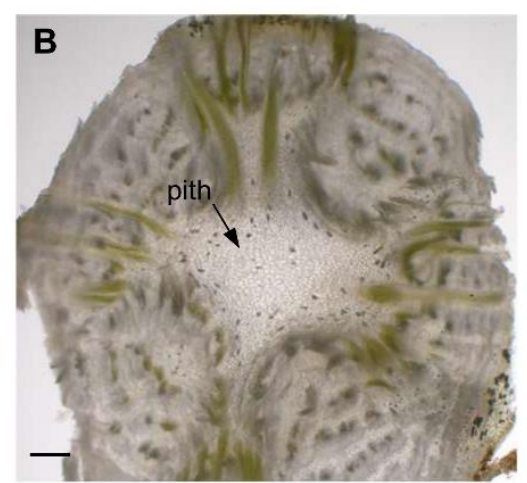
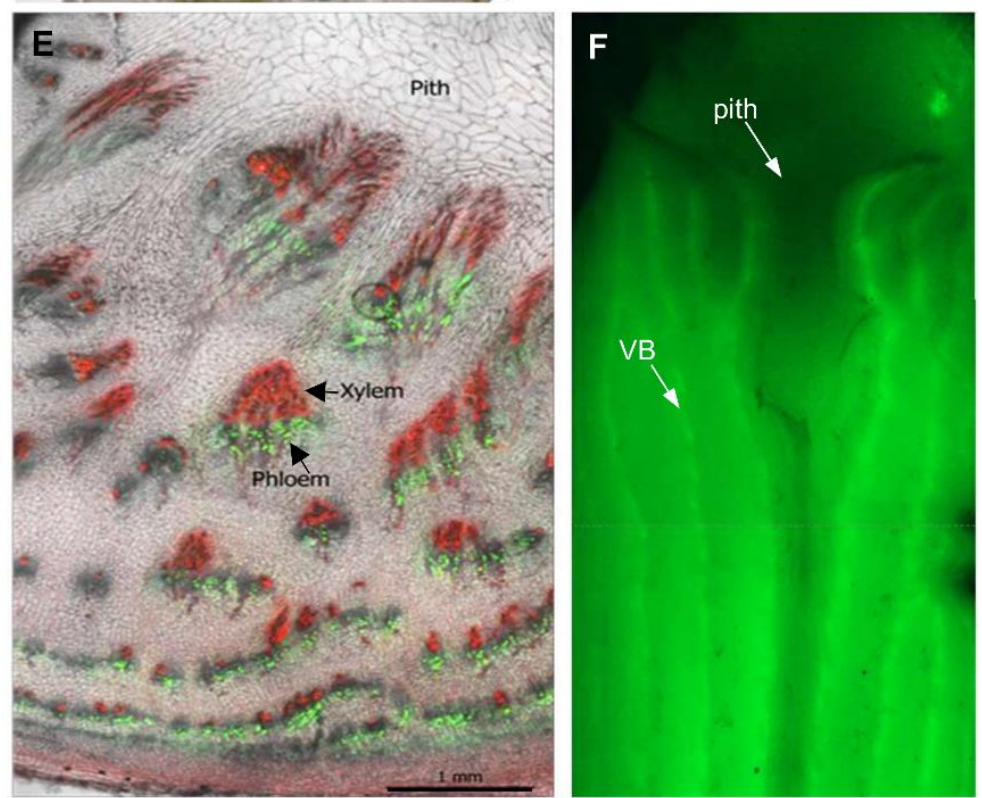

H

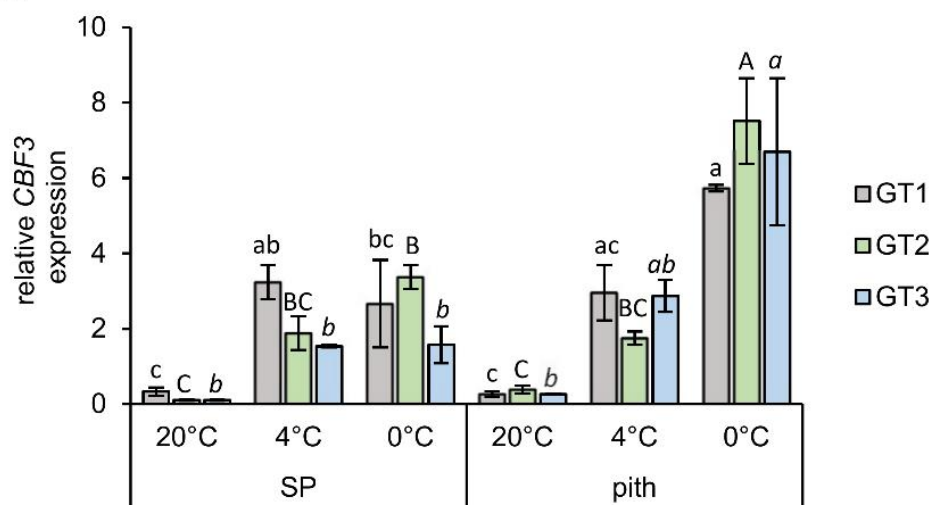

Figure 2: Morphology of the B. vulgaris pith tissue. (A) longitudinal overview section of a young taproot.

(B) Cross section of the pith tissue to reveal its cellular architecture. Scale bar representing $1 \mathrm{~mm}$. (C) FCA staining of a transverse section of the beet hypocotyl including the central pith. Lignified xylem cells are stained in red, while cellulosic cell walls are stained in blue. Scale bar representing 0.5 mm. (D) Mean cell area of storage parenchyma (SP) and pith cells measured in sugar beet cross-sections using 
ImageJ. Error bars represent the standard error over seven cross-sections. (E) Radial phloem-unloading of the fluorescent dye carboxyfluorescein (green). Cell walls were stained with propidium iodine (red), which particularly labels the thick, lignified vessels of the xylem. Scale bar represents $1 \mathrm{~mm}$. (F) Carboxyfluorescein unloading and distribution from phloem bundles in the sugar beet taproot. Arrows mark the pith tissue or vascular bundles (VB). (G) Pith and storage parenchyma were separated and expression of the shoot meristematic marker CLAVATA2 was analyzed. Error bars represent the standard error over three biological replicates. Asterisks indicate significant differences between pith and storage parenchyma (Student's $t$-test with ${ }^{*} \mathrm{p}<0.05$; ${ }^{* * *} \mathrm{p}<0.001$ for (D) and (G)). (H) Expression of the cold-induced transcription factor CBF3 in SP and pith tissue of the three analyzed genotypes. Error bars represent the standard error over three biological replicates. Letters indicate the same level of significance within each of the three genotypes at different temperatures and in different tissues, calculated via two-way ANOVA with post hoc Tukey test with $p<0.05$.

\section{ROS-related genes are upregulated in the taproot pith at low temperatures}

The prominent staining of ROS in freezing-stressed taproots prompted us to analyze antioxidant

levels and expression of ROS-related genes in pith and storage parenchyma of the different sugar beet genotypes (Fig. 3). Low temperatures lead to a significant increase of the total ascorbate content (sum of ascorbate and dehydro-ascorbate) but did not significantly alter the ratio of oxidized dehydroascorbate to reduced ascorbate in the pith tissues of GT1, GT2 and GT3 (Fig. 3A). Glutathione also increased at low temperatures reaching highest levels at $4^{\circ} \mathrm{C}$ in the pith of all three genotypes. The ratio of oxidized GSSG to reduced GSH, serving as an indicator for the ROS stress-level of the tissue, at $4^{\circ} \mathrm{C}$ in GT3 (Fig. 3B). Compared to the antioxidant contents in the pith, the contents in the storage parenchyma developed similarly with decreasing temperature, but the glutathione contents in the storage parenchyma were overall lower compared to the pith tissue of the different sugar beets

209 (Supplemental Fig. S1B). Together with levels of antioxidants, gene expression was monitored in pith and SP tissue during cold- and freezing exposure (Fig. 3C). Tissues were analyzed under control temperature $\left(20^{\circ} \mathrm{C}\right)$, after one week at $4^{\circ} \mathrm{C}$, or after an additional three days at $0^{\circ} \mathrm{C}$. Most of the tested

212 genes were upregulated in plants subjected to low temperature treatment, but the increase in 
213 expression was always stronger in the pith compared to the SP. Genes encoding typical ROS-

214 scavenging enzymes like catalase, ascorbate peroxidase and reductase, as well as glutathione

215 peroxidase showed the highest expression at $4^{\circ} \mathrm{C}$ and tuned down again at $0^{\circ} \mathrm{C}$. Interestingly,

216 expression of homologs to $\mathrm{H}_{2} \mathrm{O}_{2}$ - and superoxide-responsive transcription factor genes ZAT10 and

217 ZAT12 increased markedly at $0^{\circ} \mathrm{C}$, but not at $4^{\circ} \mathrm{C}$ (Fig. 3A) with highest upregulation observed in the

218 pith tissue, indicating that ROS accumulation increased at $0^{\circ} \mathrm{C}$ and suggesting that ROS detoxification

219 efficiency was lower at $0^{\circ} \mathrm{C}$ in comparison to $4^{\circ} \mathrm{C}$.

220 In summary, these results indicate that low temperature-dependent ROS formation and response to

221 ROS accumulation was most pronounced in the pith area of taproots and support the higher

222 accumulation of ROS revealed by ROS staining (Fig. 1F). 
bioRxiv preprint doi: https://doi.org/10.1101/2021.04.12.439442; this version posted April 13, 2021. The copyright holder for this preprint (which was not certified by peer review) is the author/funder, who has granted bioRxiv a license to display the preprint in perpetuity. It is made available under aCC-BY-NC-ND 4.0 International license.

A
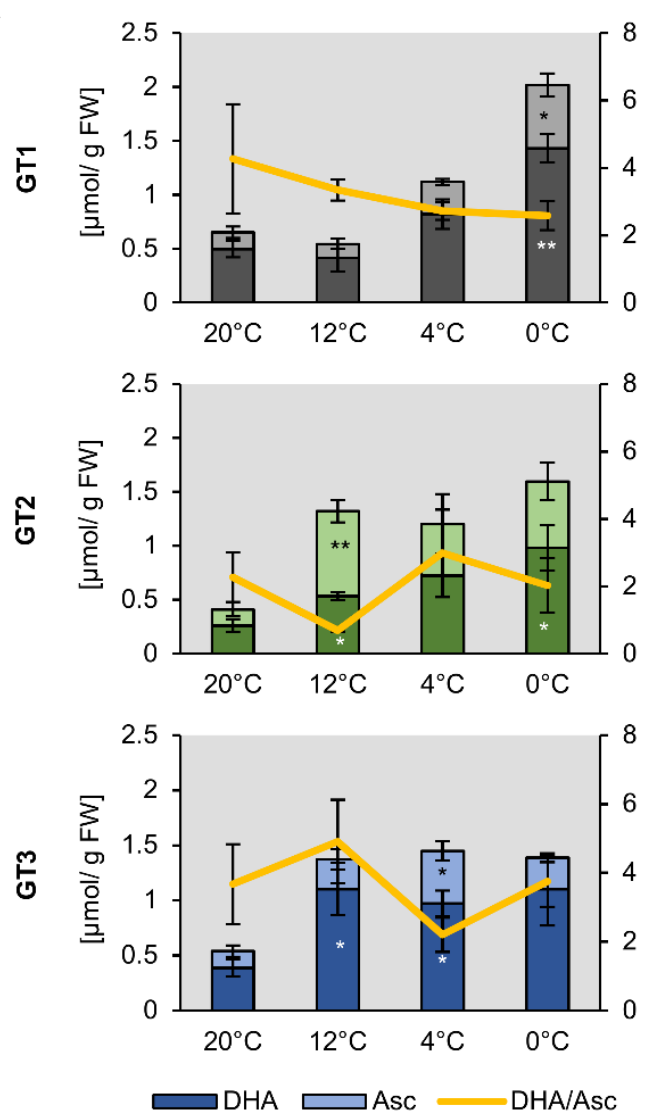

B
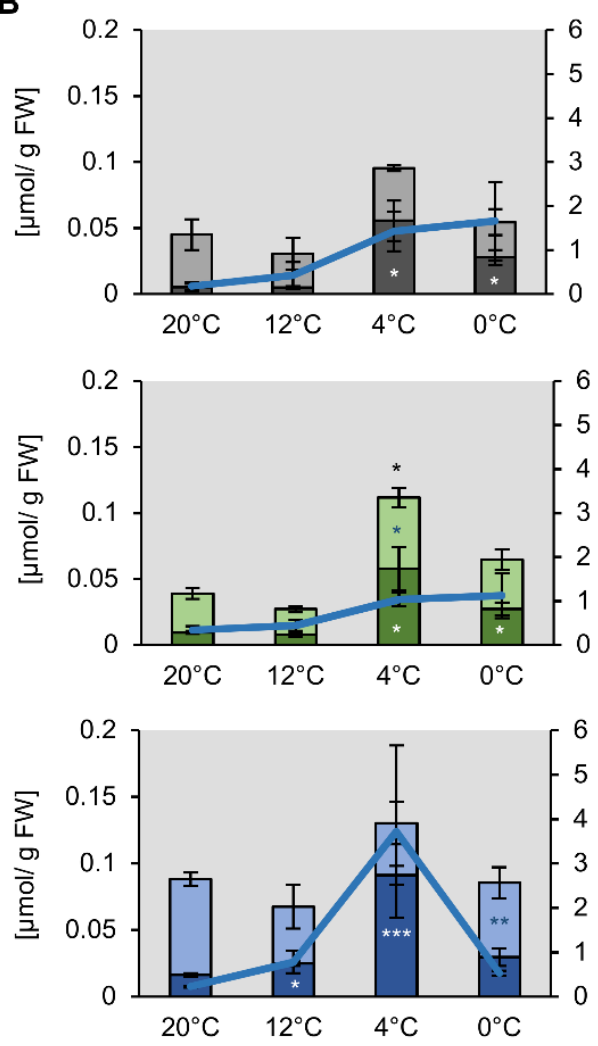

שGSG $\rightleftarrows$ GSH GSSG/GSH

C

\begin{tabular}{|c|c|c|c|c|c|c|c|c|c|c|c|}
\hline enzyme & reaction & $\begin{array}{l}\text { gene } \\
\text { symbol }\end{array}$ & $\begin{array}{l}\text { homology } \\
\text { (A.t.) }\end{array}$ & $\begin{array}{c}\text { gene locus } \\
\text { (B.v.) }\end{array}$ & GT & $\begin{array}{l}\text { Pith } \\
20^{\circ} \mathrm{C}\end{array}$ & $\begin{array}{l}\text { Pith } \\
4^{\circ} \mathrm{C}\end{array}$ & $\begin{array}{l}\text { Pith } \\
0^{\circ} \mathrm{C}\end{array}$ & $\begin{array}{c}\text { SP } \\
20^{\circ} \mathrm{C}\end{array}$ & $\begin{array}{l}\text { SP } \\
4^{\circ} \mathrm{C}\end{array}$ & $\begin{array}{l}\mathrm{SP} \\
0^{\circ} \mathrm{C}\end{array}$ \\
\hline \multirow{6}{*}{$\begin{array}{l}\text { transcription } \\
\text { factors }\end{array}$} & \multirow{3}{*}{$\mathrm{H}_{2} \mathrm{O}_{2}$ response } & \multirow{3}{*}{ ZAT10 } & \multirow{3}{*}{ AT1G27730 } & \multirow{3}{*}{ BVRB_8g189640 } & GT1 & ns & ns & $\mathrm{ns}$ & ns & ns & ns \\
\hline & & & & & GT2 & $\mathrm{b}$ & b & a & b & $\mathrm{b}$ & $a b$ \\
\hline & & & & & GT3 & $\mathrm{b}$ & $\mathrm{b}$ & a & b & b & $\mathrm{b}$ \\
\hline & \multirow{3}{*}{ superoxide response } & \multirow{3}{*}{ ZAT12 } & \multirow{3}{*}{ AT5G59820 } & \multirow{3}{*}{ BVRB_2g037310 } & GT1 & $\mathrm{bc}$ & $b c$ & a & c & ac & $a b$ \\
\hline & & & & & GT2 & $\mathrm{b}$ & $a b$ & a & b & $a b$ & $a b$ \\
\hline & & & & & GT3 & $\mathrm{b}$ & $\mathrm{b}$ & a & $\mathrm{b}$ & $\mathrm{b}$ & $\mathrm{b}$ \\
\hline \multirow{3}{*}{$\begin{array}{l}\text { Superoxide- } \\
\text { dismutase }\end{array}$} & \multirow{3}{*}{$\begin{array}{c}2 \mathrm{O}_{2}^{-}+2 \mathrm{H}^{+} \rightarrow \\
\mathrm{H}_{2} \mathrm{O}_{2}+\mathrm{O}_{2}\end{array}$} & \multirow{3}{*}{$S O D$} & \multirow{3}{*}{ AT2G28190 } & \multirow{3}{*}{ BVRB_9g206190 } & GT1 & ns & ns & ns & ns & ns & $\mathrm{ns}$ \\
\hline & & & & & GT2 & ns & ns & ns & ns & ns & ns \\
\hline & & & & & GT3 & $\mathrm{ab}$ & a & $a b$ & $\mathrm{~b}$ & $a b$ & b \\
\hline \multirow{3}{*}{ Catalase } & \multirow{3}{*}{$\begin{array}{l}2 \mathrm{H}_{2} \mathrm{O}_{2} \rightarrow \overrightarrow{\mathrm{O}}_{2} \\
2 \mathrm{H}_{2} \mathrm{O}+\mathrm{O}_{2}\end{array}$} & \multirow{3}{*}{ CAT } & \multirow{3}{*}{ AT1G20630 } & \multirow{3}{*}{ BVRB_1g021080 } & GT1 & $b$ & a & $b$ & b & $a$ & $b$ \\
\hline & & & & & GT2 & c & a & c & $\mathrm{bc}$ & $a b$ & $\mathrm{bc}$ \\
\hline & & & & & GT3 & bc & $a b$ & ac & c & a & $c$ \\
\hline \multirow{3}{*}{$\begin{array}{l}\text { Ascorbate } \\
\text { peroxidase }\end{array}$} & \multirow{3}{*}{$\begin{array}{l}2 \mathrm{Asc}+\mathrm{H}_{2} \mathrm{O}_{2} \rightarrow \\
2 \mathrm{MDA}+2 \mathrm{H}_{2} \mathrm{O}\end{array}$} & \multirow{3}{*}{$A P X$} & \multirow{3}{*}{ AT1G07890 } & \multirow{3}{*}{ BVRB_9g207350 } & GT1 & $\mathrm{bc}$ & a & $\mathrm{bc}$ & bc & $a b$ & c \\
\hline & & & & & GT2 & $a b$ & a & b & $a b$ & $a b$ & b \\
\hline & & & & & GT3 & $a b$ & a & bc & $a b$ & $a b$ & c \\
\hline \multirow{3}{*}{$\begin{array}{l}\text { Monodehydro- } \\
\text { ascorbate } \\
\text { reductase }\end{array}$} & \multirow{3}{*}{$\begin{array}{c}\mathrm{MDA}+\mathrm{NAD}(\mathrm{P}) \mathrm{H}+\mathrm{H}^{+} \rightarrow \\
\mathrm{Asc}+\mathrm{NAD}(\mathrm{P})^{-}\end{array}$} & \multirow{3}{*}{ MDAR } & \multirow{3}{*}{ AT3G52880 } & \multirow{3}{*}{ BVRB_7g159920 } & GT1 & $b c$ & a & $a b$ & $\mathrm{bc}$ & ac & $c$ \\
\hline & & & & & GT2 & c & a & c & $\mathrm{c}$ & $\mathrm{b}$ & c \\
\hline & & & & & GT3 & cd & a & $\mathrm{bc}$ & cd & $a b$ & $d$ \\
\hline & & & & & GT1 & $\mathrm{bc}$ & a & $\mathrm{bc}$ & bc & $a b$ & c \\
\hline ascorbate & $\begin{array}{c}\mathrm{DHA}+2 \mathrm{GSH} \rightarrow \\
\mathrm{Asc}+\mathrm{GSSH}\end{array}$ & DHAR & AT5G16710 & BVRB_2g039390 & GT2 & $\mathrm{b}$ & a & $\mathrm{bc}$ & $\mathrm{bc}$ & bc & c \\
\hline & & & & & GT3 & a & a & $a b$ & $a b$ & a & $\mathrm{b}$ \\
\hline & & & & & GT1 & $a b$ & a & $a b$ & $a b$ & $a b$ & $b$ \\
\hline $\begin{array}{l}\text { Glutathione } \\
\text { peroxidase }\end{array}$ & $\begin{array}{l}\mathrm{H}_{2} \mathrm{O}_{2}+2 \mathrm{GSH} \rightarrow \\
2 \mathrm{H}_{2} \mathrm{O}+\mathrm{GSSG}\end{array}$ & $G P X$ & AT4G31870 & BVRB_2g044150 & GT2 & $\mathrm{b}$ & a & $\mathrm{b}$ & bc & $\mathrm{bc}$ & c \\
\hline & & & & & GT3 & $a b$ & $a b$ & a & $\mathrm{b}$ & $\mathrm{ab}$ & $\mathrm{b}$ \\
\hline & & & & & GT1 & b & $a b$ & $a b$ & $\mathrm{~b}$ & a & $a b$ \\
\hline $\begin{array}{l}\text { Glutathione } \\
\text { reductase }\end{array}$ & $\begin{array}{c}\text { GSSG + NAD(P)H } \rightarrow \\
3 G S H+N A D(P)^{-}\end{array}$ & $G R$ & AT3G24170 & BVRB_3g069540 & GT2 & c & c & a & c & c & $\mathrm{b}$ \\
\hline & & & & & GT3 & b & a & b & b & $\mathrm{b}$ & $b$ \\
\hline
\end{tabular}


Figure 3: ROS related metabolite accumulation and gene expression. (A) and (B) Concentrations of ascorbate (Asc) and dehydro-ascorbate (DHA) (A) or reduced (GSH) and oxidized glutathione (GSSG) (B) in the pith of different sugar beet genotypes. Reduced form of the antioxidant depicted in light, oxidized form in dark color. Sugar beet plants were grown for 10 weeks at $20^{\circ} \mathrm{C}$ and were successively transferred to $12^{\circ} \mathrm{C}, 4^{\circ} \mathrm{C}$ and $0^{\circ} \mathrm{C}$ for one week each. Three plants of each genotype were harvested at a given temperature and were analyzed for their antioxidant concentration. Error bars represent the standard error over the corresponding mean. Asterisks indicate significant differences in concentrations of reduced, or of oxidized antioxidants or of the oxidized/ reduced ratio calculated in relation to the corresponding values at $20^{\circ} \mathrm{C}$ using Student's $t$-test $\left({ }^{*} \mathrm{p}<\right.$ 0,05 ; $^{* *} \mathrm{p}<0.01$ ). (C) Heat map representation of RT-qPCR analysis of ROS relates genes in taproot pith and storage parenchyma (root) from the three genotypes grown at control $\left(20^{\circ} \mathrm{C}\right)$ or low temperatures $\left(4^{\circ} \mathrm{C}\right.$ and $0^{\circ} \mathrm{C}$ ). Data represents the mean of three independent biological replicates. Different letters within individual tiles denote significant differences between tested conditions and tissues according to two-way ANOVA with post-hoc Tukey HSD testing ( $\mathrm{p}<0.05)$. exposure to subzero temperatures

241 In addition to the antioxidants ascorbate and glutathione, also other compounds like sugars and amino acids contribute to ROS scavenging. Since ROS accumulation was pronounced in the pith region

243 of taproots, we analyzed the low temperature-dependent accumulation of such metabolites and their 244 spatial distribution between leaf, pith, and storage parenchyma tissues. In total, 36 compounds were 245 measured and their contents are listed in Supplemental Table S1. A PC analysis, loaded with the $2460^{\circ} \mathrm{C} / 20^{\circ} \mathrm{C}$ fold-changes of these compounds PC1 separated pith and SP tissues (Supplemental Figure

247 S2). The metabolic reaction of the storage parenchyma of the two more tolerant genotypes, GT2 and 248 GT3, was similar, but differed from that of GT1 (Supplemental Figure S2). The separation of leaf tissue from pith and storage parenchyma was mainly based on changes in raffinose concentrations (Supplemental Figure S2). Different degrees of changes in starch content mainly contributed to the separation of pith and storage tissue (Supplemental Figure S2). Under control temperatures, the

Figure S3). After exposure to frost, starch decreased drastically in leaves, but was not significantly 
254 altered in pith and storage parenchyma (Supplemental Figure S3). However, only low

255 concentrations of starch are present in the sugar beet taproot tissue in general and therefore starch

256 is unlikely to contribute significantly to frost-tolerance (Rodrigues et al., 2020; Turesson et al., 2014).

257 Changes in starch content, however, depend on soluble sugar metabolism. Consistently, frost also

258 massively increased concentrations of glucose and fructose in leaves, but not significantly in pith and

259 storage tissues (Supplemental Figure S3). Sucrose concentrations were highest in the storage

260 parenchyma and lowest in the leaves (Supplemental Figure S3). In both tissues no significant

261 changes in sucrose concentrations could be observed between control and freezing conditions, or

262 between genotypes (Supplemental Figure S3). In the pith tissue, concentrations of sucrose differed

263 at $20^{\circ} \mathrm{C}$ between genotypes, but fluctuated only marginally within and between genotypes at $0^{\circ} \mathrm{C}$

\section{4 (Supplemental Figure S3).}

265 Genotype and temperature-dependent accumulation of inositol, galactinol, and raffinose

266 As concentrations of glucose, fructose and sucrose differed only marginally in pith tissues of the three

267 genotypes after a shift from control to freezing conditions, we analyzed the contents of raffinose as

268 well as of inositol and galactinol, which are precursors for raffinose synthesis (Fig. 4A), because

269 raffinose was shown to possess second order rate constants for ROS scavenging, comparable or even

270 higher than those of glucose, fructose and sucrose and the antioxidant ascorbate (Nishizawa et al.,

271 2008). Similar to the sugars glucose, fructose, and sucrose, the pith tissue had inositol, galactinol and

272 raffinose concentrations in-between of those measured for leaves and taproot SP (Fig. 4). Inositol

273 content of the leaves at $20^{\circ} \mathrm{C}$ was highest in GT2 and GT3. Upon $0^{\circ} \mathrm{C}$ exposure, inositol levels increased

274 to comparable amounts in the leaf tissue of all three genotypes (Fig. 4B). However, in the pith and

275 storage parenchyma, inositol levels remained unchanged upon exposure to freezing temperatures

276 (Fig. 4B). Like its precursor inositol (Fig. 4A), concentrations of galactinol increased in leaves at $0^{\circ} \mathrm{C}$

277 two- to three-fold (Fig. 4C). Galactinol concentrations also increased in the pith and storage tissue at 
$2780^{\circ} \mathrm{C}$. In the pith galactinol accumulated at $0^{\circ} \mathrm{C}$ to concentrations twice as high as compared to the SP

279 (Fig. 4C). Notably, freezing temperatures boosted raffinose concentrations at least 10-fold, in GT3

280 leaves, and up to 80-fold, in GT1 leaves, in comparison to the corresponding leaf-tissue at $20^{\circ} \mathrm{C}($ Fig.

281 4D). In the pith tissue, raffinose content increased in GT2 and GT3 at $0^{\circ} \mathrm{C}$. At $0^{\circ} \mathrm{C}$, raffinose levels of

282 GT2 and GT3 exceeded those of GT1 at least two-fold in the pith. Interestingly, GT2, the cultivar with

283 the highest freezing survival rates (Fig. 1A), had about 80\% higher raffinose concentrations in

284 comparison to GT1 and GT3 already under control conditions (Fig. 4D). In SP, raffinose

285 concentrations were slightly increased or remained unchanged at $0^{\circ} \mathrm{C}$ in comparison to $20^{\circ} \mathrm{C}$ (Fig.

286 4D). 

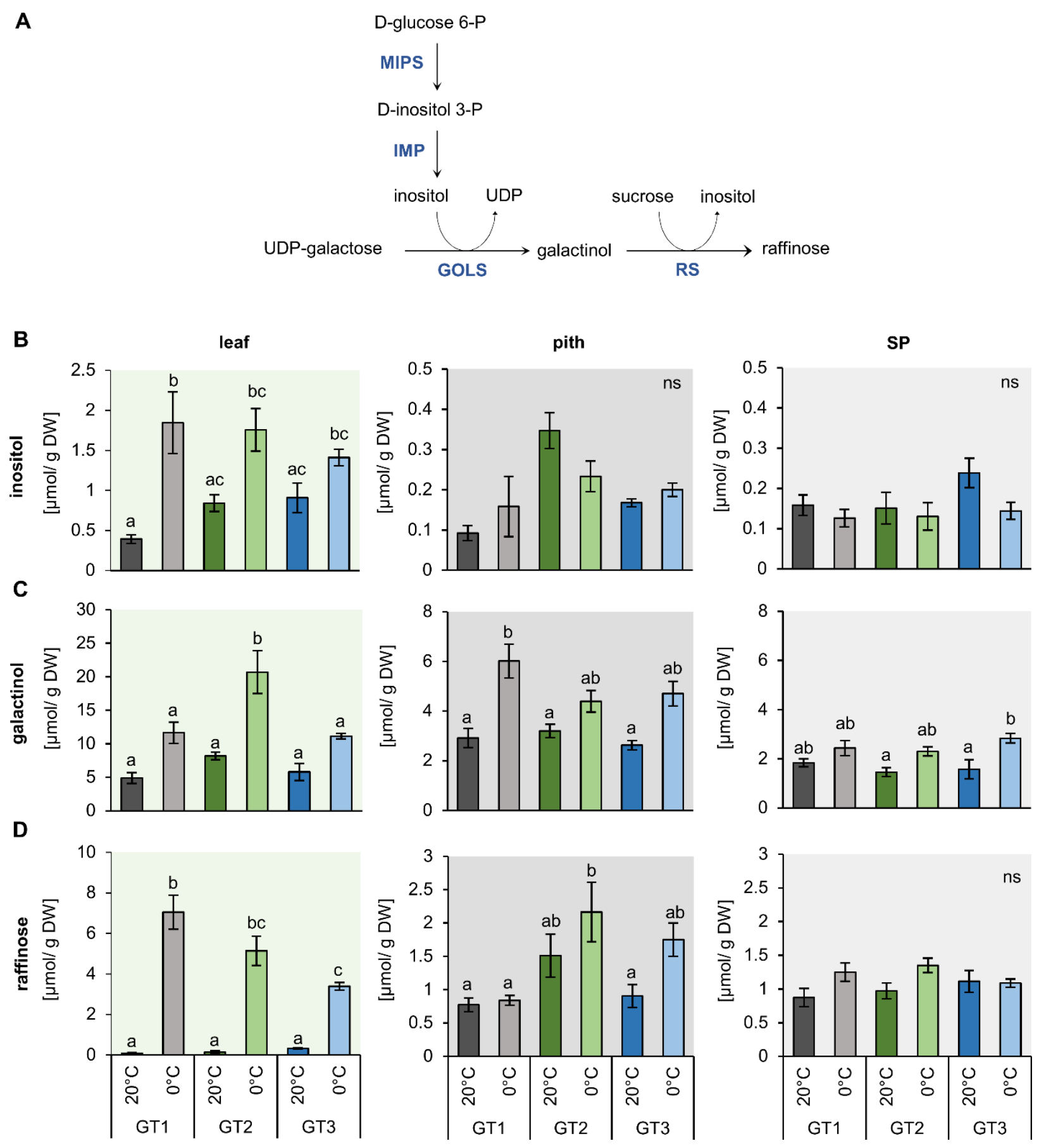

Figure 4: Inositol and raffinose synthesis and their concentrations in leaf, pith and storage parenchyma tissue under control and freezing temperatures. (A) Schematic representation of inositol and raffinose synthesis in plants. (B) to (D) Raffinose and intermediates in raffinose synthesis were measured in plants grown at $20^{\circ} \mathrm{C}$ and plants transferred to $12^{\circ} \mathrm{C}, 4^{\circ} \mathrm{C}$ and harvested at $0^{\circ} \mathrm{C}$ soil temperature. Plants were dissected in the three different tissues leaf, pith and root while harvesting at the corresponding temperatures. Inositol (B), galactinol (C) and raffinose (D) concentrations represent the mean of three biological replications for each of the tested cultivars. Error bars represent 
294 the standard error over the corresponding mean. Letters indicate the same level of significance for each measured

295 concentration, calculated via two-way ANOVA with post hoc Bonferroni test with $\mathrm{p}<0.05$.

297 Inositol-, galactinol- and raffinose-biosynthesis genes are differentially expressed in leaf and

298 taproot tissue in response to freezing

299 To reveal global patterns of gene expression in response to freezing stress we performed comparative

300 RNASeq analysis of leaf and taproot tissues of the three different genotypes at control and freezing 301 temperatures. However, this analysis came with the limitation that we did not separate pith and 302 storage parenchyma but instead analyzed total taproots. RNA-Seq reads were mapped to the sugar

303 beet reference genome (Dohm et al., 2013) and revealed global rearrangement of gene expression in 304 leaf and taproot tissue upon freezing exposure (Fig. 5A, B and Fig. 5F, G).

305 To get a more general overview on regulation of different cellular pathways and reactions, RNASeq 306 data were mapped into different functional groups, based on MapMan mapping. We then calculated

307 the mean logarithmic fold change (log2FC) of all genes with $\log 2 \mathrm{FC} \neq 0$ mapped in each of these 308 functional groups, without filtering for significant changes prior to analysis. This analysis revealed 309 downregulation of genes involved in photosynthesis in leaf tissue at $0^{\circ} \mathrm{C}$ (Fig. 5C). In contrast, minor 310 CHO metabolism was the most prominently upregulated functional group in the leaf (Fig. 5C) and 311 also in the taproot tissue (Fig 5H). Minor CHO metabolism separates into the sub-bins raffinose, 312 inositol, sugar alcohols, galactose, trehalose, callose synthesis, and sugar kinases. The mean log2FCs 313 of genes involved in each of these sub-bins ranged from lowest values for sugar alcohols to highest 314 for raffinose metabolism in leaves and from lowest mean $\log 2 \mathrm{FC}$ for inositol to highest for raffinose 315 metabolism in taproot tissue (Fig. 5D and 5H). The latter opposite regulation of inositol and raffinose 316 in taproots is interesting because inositol is essential for raffinose biosynthesis and the high log2FCs 317 for raffinose in both leaves and taproots suggested increased utilization of carbon for raffinose 
318 biosynthesis under low temperatures. To reveal first genotype dependent differences in the

319 expression of minor CHO genes in the different genotypes, violin plots showed the distribution of

$320 \log 2 \mathrm{FC}$ over minor CHO genes in leaf and taproot tissues. While most of those genes show log2FCs

321 between -2 and 2 in both leaf and taproot tissues upon freezing treatment (Fig. 5E and 5J), in GT2 a

322 few genes showed $\log 2 \mathrm{FC}$ of up to 7 in the leaves and up to 10 in the taproot (Fig. 5E and 5J). Overall

323 the number of highly upregulated genes in minor CHO metabolism of GT2 was higher than in GT1 and

324 GT3, independent of the tissue (Fig. 5E and 5J). To reveal possible genotype specific regulation of

325 genes involved in raffinose and its precursors synthesis, we extracted transcript levels for those genes

326 upon exposure to $0^{\circ} \mathrm{C}$ (Table 1). 
bioRxiv preprint doi: https://doi.org/10.1101/2021.04.12.439442; this version posted April 13, 2021. The copyright holder for this preprint (which was not certified by peer review) is the author/funder, who has granted bioRxiv a license to display the preprint in perpetuity. It is made available under aCC-BY-NC-ND 4.0 International license.
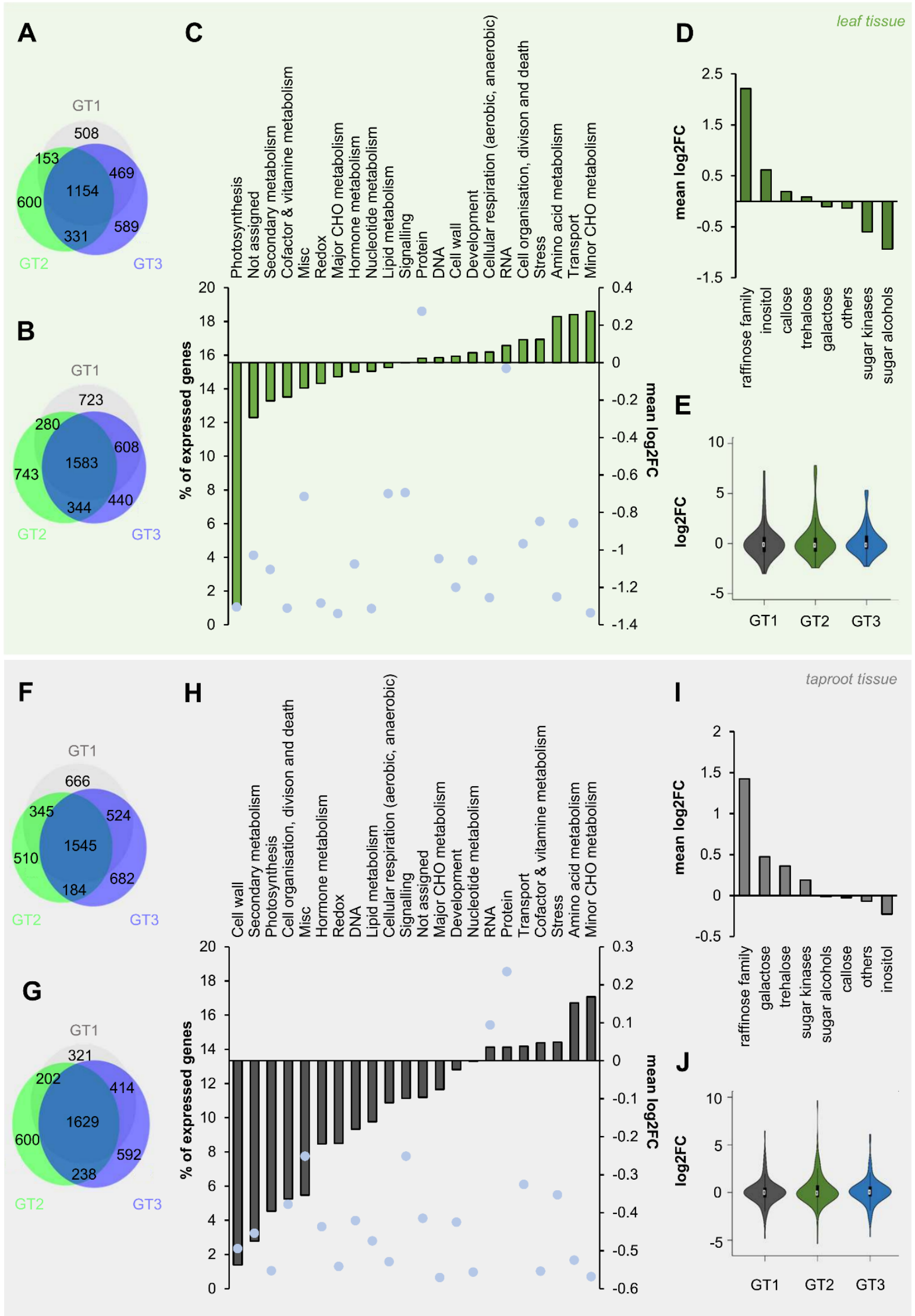
329 Figure 5: Changes in gene expression of $B$. vulgaris leaf and taproot tissues upon freezing treatment. (A,

330 b; F, G) Venn diagrams of differentially expressed genes in leaves (A, B) and taproots (F, G). Numbers of up $331(\log 2 \mathrm{FC} \geq 1 ; \mathrm{A}, \mathrm{F})$ or down $-(\log 2 \mathrm{FC} \leq-1 ; \mathrm{B}, \mathrm{G})$ regulated genes (with a FDR $\leq 0.05)$ in leaves $(\mathrm{A}, \mathrm{B})$ or taproots $332(\mathrm{~F}, \mathrm{G})$ are given inside the circles of the diagram. $\log 2 \mathrm{FC} 20^{\circ} \mathrm{C} / 0^{\circ} \mathrm{C}$ of all expressed genes with $\log 2 \mathrm{FC} \neq 0$ in 333 leaf $(\mathrm{C})$ and taproot tissue $(\mathrm{H})$ were functionally grouped and plotted against the number of genes in each group 334 given in percent of the total number of expressed genes (blue dots). (D) and (I) mean $\log _{2} \mathrm{FC} 20^{\circ} \mathrm{C} / 0^{\circ} \mathrm{C}$ of genes 335 with $\log 2 \mathrm{FC} \neq 0$ of different metabolic pathways included in the functional group of "minor CHO metabolism" 336 in leaf (D) and taproot tissue (I). Log2FCs represent the mean of the three different B. vulgaris genotypes GT1, 337 GT2 and GT3, each measured in three biological replications for (C, D) in the leaf and (H, I) in the taproot. 338 Log2FCs of genes included in the functional group of "minor CHO metabolism" are shown as violin plots for the 339 corresponding tissues leaf (E) and taproot (J). White circles show the medians, box limits indicate the 25th and 340 75th percentiles as determined by R software, whiskers extend 1.5 times the interquartile range from the 25 th 341 and 75th percentiles and polygons represent density estimates of data and extend to extreme values in violin 342 plots.

343 Table 1: $\log 2 \mathrm{FC} 20^{\circ} \mathrm{C} / 0^{\circ} \mathrm{C}$ of expression of enzymes involved in inositol-, galactinol and raffinose 344 synthesis of leaf and taproot tissue (root) of three differential B. vulgaris genotypes GT1, GT2 and GT3. Data 345 have been extracted from the RNASeq analyis. Significant up- or downregulation at $0^{\circ} \mathrm{C}$ in comparison to the 346 expression at $20^{\circ} \mathrm{C}$ is indicted by bold numbers. Significance was calculated using Student's $t$-test with false 347 discovery rate testing $\left(\mathrm{p}_{\text {adj }}<0.1\right)$.

\begin{tabular}{|c|c|c|c|c|c|c|c|c|c|}
\hline Function & $\begin{array}{c}\text { Gene identifier } \\
\text { (RefBeet1.2) }\end{array}$ & $\begin{array}{l}\text { Gene } \\
\text { name }\end{array}$ & Annotation & $\begin{array}{l}\text { leaf } \\
\text { GT1 }\end{array}$ & $\begin{array}{l}\text { leaf } \\
\text { GT2 }\end{array}$ & $\begin{array}{l}\text { leaf } \\
\text { GT3 }\end{array}$ & $\begin{array}{l}\text { root } \\
\text { GT1 }\end{array}$ & $\begin{array}{l}\text { root } \\
\text { GT2 }\end{array}$ & $\begin{array}{l}\text { root } \\
\text { GT3 }\end{array}$ \\
\hline \multirow{6}{*}{ 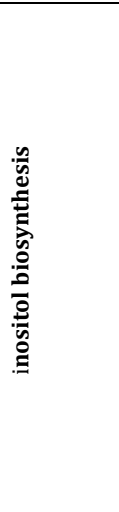 } & Bv6_135490_ioyj.t1 & MIPS & $\begin{array}{l}\text { inositol-3-phosphate synthase } \\
\text { (M. crystallinum) }\end{array}$ & 3.46 & 3.68 & 3.17 & 0.96 & 1.85 & 0.49 \\
\hline & Bv3_059200_pzry.t1 & IMP1 & $\begin{array}{l}\text { type I inositol polyphosphate } 5 \text { - } \\
\text { phosphatase (A.thaliana) }\end{array}$ & -1.89 & -1.02 & -0.96 & -3.27 & -2.49 & -3.04 \\
\hline & Bv4_097150_xtnp.t1 & IMP2 & $\begin{array}{l}\text { bifunctional phosphatase IMPL2, precursor } \\
\text { (A.thaliana) }\end{array}$ & 0.60 & 0.32 & 0.91 & 0.89 & 0.58 & 0.65 \\
\hline & Bv5_127150_wkgm.t1 & IMP3 & $\begin{array}{c}\text { phosphatase IMPL1, precursor } \\
\text { (A. thaliana) }\end{array}$ & -1.19 & -1.27 & -1.08 & -0.01 & -0.01 & 0.20 \\
\hline & Bv8_184830_ufws.t1 & IMP4 & $\begin{array}{l}\text { inositol monophosphatase } \\
\text { (M. crystallinum) }\end{array}$ & 0.22 & 0.31 & 0.71 & -0.56 & -0.50 & -0.64 \\
\hline & Bv9_217040_nmtf.t1 & IMP5 & $\begin{array}{l}\text { bifunctional phosphatase IMPL2, precursor } \\
\qquad \text { (A.thaliana) }\end{array}$ & -0.27 & -0.21 & -0.40 & -0.46 & -0.55 & -0.81 \\
\hline \multirow{4}{*}{ 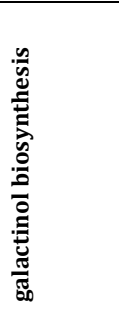 } & Bv5_122490_gtzu.t1 & GOLS1 & galactinol synthase 1 & 7.18 & 7.57 & 5.33 & 2.33 & 1.79 & 2.24 \\
\hline & Bv4_079980_rfmk.t1 & GOLS2 & $\begin{array}{c}\text { (A. thaliana) } \\
\text { galactinol synthase } 2 \\
\text { (S. lycopersicum) }\end{array}$ & 5.65 & 7.06 & 5.01 & 0.55 & 2.97 & 1.14 \\
\hline & Bv4_080000_ugrr.t1 & GOLS3 & $\begin{array}{l}\text { galactinol synthase } 2 \\
\text { (S. lycopersicum) }\end{array}$ & 7.25 & 7.81 & 5.26 & 6.46 & 9.88 & 6.11 \\
\hline & Bv6_155630_dgxc.t1 & GOLS4 & $\begin{array}{l}\text { galacturonosyltransferase-like } \\
\text { (A. thaliana) }\end{array}$ & -3.00 & -2.43 & -1.42 & -4.82 & -5.37 & -4.64 \\
\hline
\end{tabular}




\begin{tabular}{|c|c|c|c|c|c|c|c|c|c|}
\hline \multirow{5}{*}{ 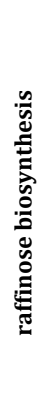 } & Bv4_091140_xstd.t1 & RS1 & $\begin{array}{c}\text { galactinol-sucrose galactosyltransferase } 1 \\
\text { (A. thaliana) }\end{array}$ & -2.94 & -2.30 & -2.28 & -2.22 & -1.57 & -2.39 \\
\hline & Bv_006460_trdy.t1 & RS2 & $\begin{array}{c}\text { galactinol-sucrose galactosyltransferase } 2 \\
\text { (A. thaliana) }\end{array}$ & 0.86 & 0.78 & 0.91 & 2.09 & 1.95 & 1.82 \\
\hline & Bv7_177120_psfp.t1 & RS3 & $\begin{array}{c}\text { galactinol-sucrose galactosyltransferase } 2 \\
\text { (A. thaliana) }\end{array}$ & 0.55 & 0.54 & 0.33 & -0.09 & -0.29 & -0.13 \\
\hline & Bv1_011340_dsoj.t1 & RS5 & $\begin{array}{l}\text { galactinol-sucrose galactosyltransferase }(P . \\
\text { sativum) }\end{array}$ & 4.51 & 6.26 & 4.77 & 3.33 & 3.36 & 2.89 \\
\hline & Bv8_193750_qhjs.t1 & RS6 & $\begin{array}{c}\text { galactinol-sucrose galactosyltransferase } 6 \\
\text { (A. thaliana) }\end{array}$ & -0.19 & -0.45 & -0.15 & 0.31 & 0.50 & -0.33 \\
\hline
\end{tabular}

349 De-novo inositol biosynthesis occurs via the enzymes myo-inositol phosphate synthase (MIPS) and 350 inositol monophosphatase (IMP) (Fig. 4A; Loewus and Murthy, 2000). MIPS catalyzes the rate 351 limiting step in inositol de-novo synthesis (Donahue et al., 2010), isomerization of glucose-6352 phosphate to inositol-3-phosphate. IMP then catalyzes de-phosphorylation of inositol-3-phosphate to 353 inositol. In the B. vulgaris genome (Dohm et al., 2013), we identified one sequence with high homology 354 to MIPS (BvMIPS, Bv6_135490_ioyj.t1) and five sequences with high homology to IMP (BvIMP1, 355 Bv3_059200_pzry.t1; BvIMP2, Bv4_097150_xtnp.t1; BvIMP3, Bv5_127150_wkgm.t1; BvIMP4, 356 Bv8_184830_ufws.t1; BvIMP5, Bv9_217040_nmtf.t1).

357 Frost enhanced expression of BvMIPS in both, leaves and taproots, with the strongest induction 358 occurring in the freezing-tolerant cultivar, GT2 (Table 1). Expression of the five IMP genes was 359 differentially regulated upon $0^{\circ} \mathrm{C}$. In leaves, $I M P 1, I M P 3$, and $I M P 5$ were downregulated, while $I M P 2$ 360 and IMP4 genes were slightly upregulated at $0^{\circ} \mathrm{C}$. In taproots, IMP expression was downregulated, 361 except for IMP2 (Table 1). However, IMP genes were not regulated in a genotype-dependent manner. 
363 Inositol can be fused to UDP-galactose to form alpha-D-galactosyl-(1->3)-1D-myo-inositol

364 (galactinol) and UDP. This reaction is catalyzed by galactinol synthase (GOLS) and is required for

365 subsequent biosynthesis of raffinose (Fig. 4A). We identified four genes with homology to galactinol

366 synthases from tomato (Solanum lycopersicum) or Arabidopsis in the sugar beet genome (Table 1,

367 Supplemental Figure S4). The expression of three of the four GOLSs (BvGOLS1 to 3) was strongly

368 upregulated at $0^{\circ} \mathrm{C}$ in leaves and in taproots. The log2FCs for GOLS2 and GOLS3 in leaves and

369 especially in the taproot of GT2 exceeded those of the less freezing tolerant genotypes GT1 and GT3

370 (Table 1). The gene coding for a fourth GOLS isoform, GOLS4, was downregulated at $0^{\circ} \mathrm{C}$, independent

371 of the tissue and genotype (Table 1). Phylogenetic analysis revealed that BvGOLS4

372 (Bv6_155630_dgxc.t1) was only distantly related to the other sugar beet GOLS isoforms

373 (Supplemental Figure S4) and therefore may not encode a functional GOLS or a GOLS relevant for

374 the plants freezing response.

375

376 The ultimate step of raffinose biosynthesis is the transfer of the galactinol's galactose moiety to

377 sucrose via the enzyme raffinose synthase (RS). During this reaction, inositol is released from

378 galactinol (Fig. 4A). We identified seven RS isoforms in the sugar beet genome (Supplemental Figure

379 S4). Two isoforms, BvRS4 and BvRS7 were not changed in their expression. Of the remaining 5

380 isoforms, two RS, $B v R S 2$ and $B v R S 5$, were upregulated in the leaf and taproot tissue at $0^{\circ} \mathrm{C}$ (Table 1).

381 Overall, BvRS5 (Bv1_011340_dsoj.t1), the closest homolog to AtRS5 (Supplemental Figure S4),

382 showed the highest upregulation at $0^{\circ} \mathrm{C}$ (Table 1). Similar to the GOLS genes, upregulation was

383 strongest in freezing-tolerant GT2 plants, independent of the tissue (Table 1). 
390 during the freezing response of sugar beet plants (Figure 5 and Table 1). Because of the different

391 sensitivities of the pith of the three genotypes to freezing, we analyzed the expression of galactinol

392 and raffinose biosynthesis-related genes in taproot tissues with RT-qPCR (Fig. 6). Among galactinol

393 synthases, GOLS1 was the most abundant isoform in the pith and storage parenchyma (Fig. 6A),

394 however, upregulation of gene expression in terms of fold-change was strongest for GOLS2 and GOLS3

395 at $0^{\circ} \mathrm{C}$ (Fig. 6A). Expression of GOLS2 and GOLS3 was highest in GT1 and GT3 at $0^{\circ} \mathrm{C}$ (Fig. 6A). The

396 two RS isoforms RS2 and RS5 showed comparable abundance in the pith of all three genotypes at

397 control temperatures. Abundancy of RS2 was slightly higher in the storage parenchyma, while RS5

398 abundancy in the SP was comparable to the pith at $20^{\circ} \mathrm{C}$ (Fig. 6B). Additionally, the upregulation of

399 RS expressions in terms of fold- change in the pith was comparable between RS2 and RS5 expression

400 in GT2 and GT3. Overall, GT3 showed the highest fold-change upregulation of RS2 and RS5 in the pith

401 (Fig. 6B). In GT1 pith tissue, upregulation of $R S 2$ expression was comparable to that in GT2 (Fig. 6B).

402 While $R S 2$ was upregulated in the pith of GT1 upon exposure to $0^{\circ} \mathrm{C}$, GT1 pith tissue lacked the ability

403 of upregulation of $R S 5$ upon exposure to freezing temperatures (Fig. 6B). While RS5 expression

404 increased more than 15-, and 20- fold in the pith of GT2 and GT3 respectively, expression remained

405 unaltered in the pith of the less tolerant GT1 upon $0^{\circ} \mathrm{C}$ (Fig. 6B). GT1 failed to induce $R S 5$ in the pith

406 tissue in comparison to GT2 and GT3 and induction of RS5 expression was highest in SP of this

407 genotype (Fig. 6B). Taken together, expression of $R S$ genes in the pith was upregulated to a greater

408 extent in the freezing-tolerant cultivars GT2 and GT3, and to a lower extent in sensitive GT1 (Fig. 6B),

409 which is in line with the low raffinose concentrations in the pith of this genotype at $0^{\circ} \mathrm{C}$ (Fig. 4D). 

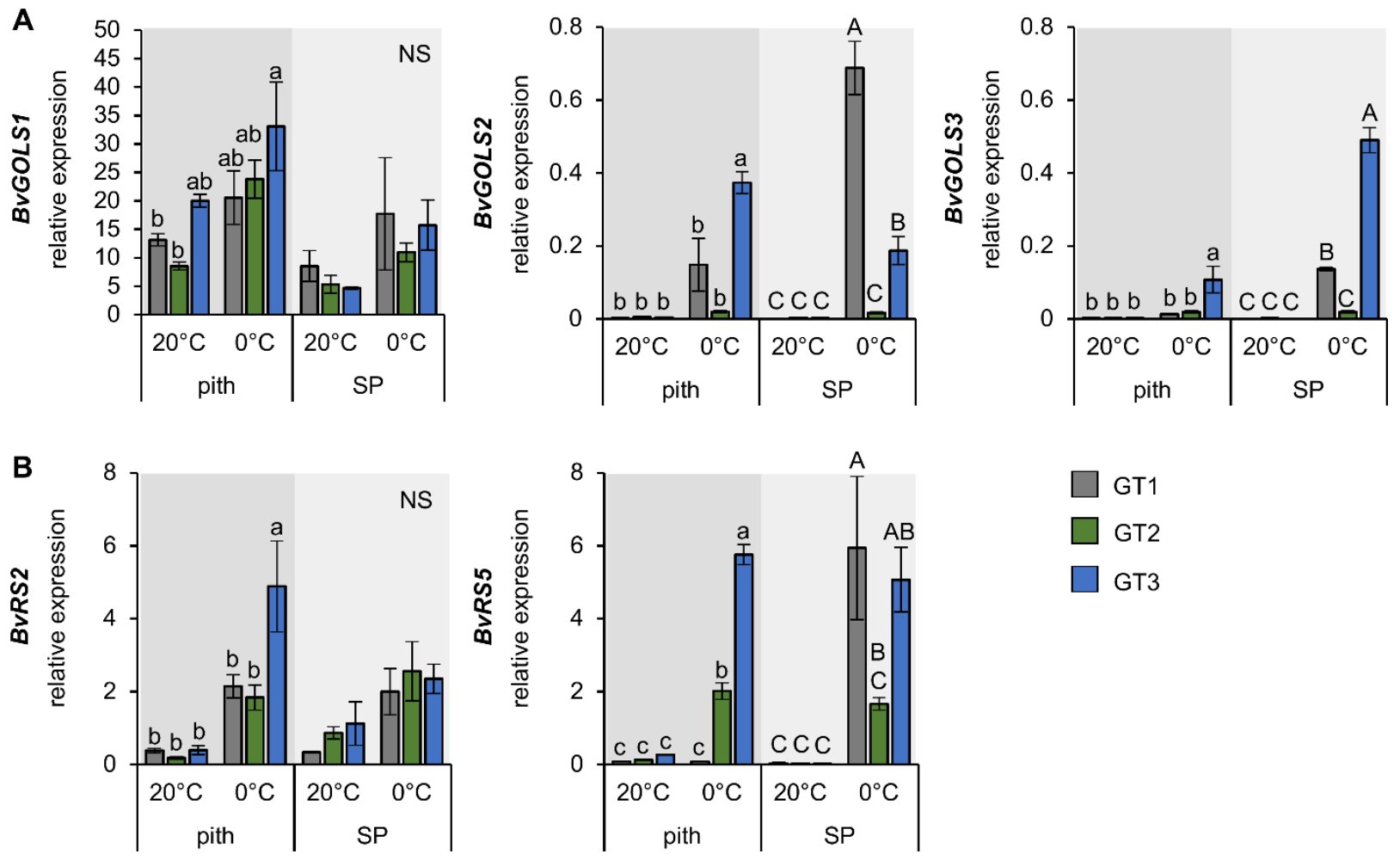

\section{$\square$ GT1 \\ $\square$ GT2 \\ $\square$ GT3}

411 Figure 6: Expression of $G O L S$ and $R S$ isoforms in pith and storage parenchyma samples of three contrasting $B$.

412 vulgaris cultivars. Relative expression of GOLS (A) and $R S$ isoforms (B) in the pith and storage parenchyma at $20^{\circ} \mathrm{C}$ 413 and freezing treatment at $0^{\circ} \mathrm{C}$. Bars represent means from three biological replicates \pm standard error. Different letters 414 indicate significant differences between genotypes within a tissue according to two-way ANOVA with post hoc Tukey 415 test $(\mathrm{p}<0.05)$.

\section{DISCUSSION}

418 During exposure to low temperatures $\left(4^{\circ} \mathrm{C}\right)$, sugar beet plants undergo a transformation in 419 metabolite- and gene expression profiles (Rodrigues et al., 2020). However, as we show here, not only 420 chilling but also freezing treatment induces changes in metabolite concentrations and gene 421 expression. Because Beta vulgaris is a freezing-sensitive plant showing severe freezing-induced tissue 422 damage (Fig. 1C), it is of high interest to analyze the plant's response to sub-zero temperatures on a molecular basis. 
424 Transcriptomic analysis revealed that genes involved in minor CHO metabolism were strongly 425 upregulated in both leaf- and taproot tissues (Fig. 5 and Table 1). While genes from this functional 426 group were upregulated, genes involved in photosynthesis were downregulated upon freezing 427 treatment (Fig. 5). Both the downregulation of photosynthesis-related genes and the decrease in 428 photosynthetic activity (Fig. 1D) at low temperatures confirmed our recent results, where cold $\left(4^{\circ} \mathrm{C}\right)$ 429 treatment led to lower photosynthetic activity and downregulation of photosynthesis-genes in sugar 430 beet leaves (Rodrigues et al., 2020). Such effects on photosynthetic related protein level has also been 431 observed in leaves of Arabidopsis (Fanucchi et al., 2012; Janmohammadi et al., 2015) and may be a 432 direct effect of electron overflow at photosynthetic reaction centers because of a slow-down of Calvin433 Benson cycle reactions (Pommerrenig et al., 2018; Strand et al., 1997).

434 Sugar concentrations, especially those of monosaccharides, increased at $0^{\circ} \mathrm{C}$ in the leaf tissue 435 (Supplemental Figure S3) in a similar manner as in other plant species, where metabolites 436 accumulate during prolonged cold treatment (Ho et al., 2020; Klemens et al., 2014; Usadel et al., 437 2008). Overall, concentrations of sucrose were highest in the heterotrophic tissues, whereas 438 concentrations of the monosaccharides glucose and fructose were highest in the leaves 439 (Supplemental Figure S3). This pattern was expected, as sucrose is the main storage carbohydrate 440 of taproots (Giaquinta, 1979; Rodrigues et al., 2021). The pith tissue harbored intermediate 441 concentrations of both, monosaccharides and sucrose, as - in contrast to the storage parenchyma - it 442 is not directly supplied with sucrose by the phloem. The application of the phloem mobile stain CFDA 443 (Knoblauch et al., 2015; Mehdi et al., 2019; Pommerrenig et al., 2020) to source leaves allowed 444 visualization of phloem fluxes into and within the sugar beet taproot and indicated that sucrose was 445 transported in the taproot via the phloem in a similar manner. CFDA staining revealed organization 446 of the phloem in vascular rings surrounding the pith (Fig. 2). Sugar translocated via and unloaded 447 from the phloem can therefore not directly enter the pith tissue (Fig. 2) (Artschwager, 1926; Jahnke 448 et al., 2009; Metzner et al., 2014). This observation correlates with lower amounts of sucrose in the 
449 pith tissue (Supplemental Figure S3). The size of pith cells was markedly larger in comparison to

450 storage parenchyma cells and morphology of the pith already suggests lower sucrose concentrations

451 in its cells, since sucrose concentration has been reported to decline with cell size in sugar beet (Bellin

452 et al., 2007).

453 Our observations show that post-freezing rot of taproot tissue mainly originates from the pith tissue.

454 High ROS accumulation at freezing temperatures as indicted by intense DAB- and NBT-derived

455 staining (Fig. 1 and Supplementary Figure S1) and strong upregulation of ROS marker genes ZAT10

456 and ZAT12 (Fig. 3) might be causative for the observed tissue damage resulting in post-freezing

457 rotting of the pith. Genes encoding factors of the ROS detoxification system were markedly

458 upregulated at chilling temperatures $\left(4^{\circ}\right)$ or freezing temperatures (Fig. 3). Raffinose biosynthesis

459 genes on the other hand were also increased at $4^{\circ} \mathrm{C}$ but maintained high mRNA levels at $0^{\circ} \mathrm{C}(\mathbf{F i g}, 5$

460 and Table 1).

461 Raffinose is known to accumulate under abiotic stress conditions such as drought (Li et al., 2020) or

462 cold in different plant species including Arabidopsis and rice (Oryza sativa) (Saito and Yoshida, 2011;

463 Taji et al., 2002). Raffinose is synthesized by a transfer reaction of galactosyl units to sucrose,

464 involving the enzymes galactinol synthase (GOLS) and raffinose synthase (RS) (Fig. 4A). Both

465 enzymes were reported to be upregulated during cold treatment in Ajuga reptans, Medicago falcata,

466 Medicago sativa or Arabidopsis thaliana (Cunningham et al., 2003; Egert et al., 2013; Sprenger and

467 Keller, 2000; Zhuo et al., 2013; Zuther et al., 2004). The enzymes myo-inositol phosphate synthase

468 (MIPS) and inositol monophosphatase (IMP) are indirectly involved in raffinose synthesis, as they

469 catalyze the de novo synthesis of inositol, which is required for the formation of the galactosyl donor

470 galactinol (Saravitz et al., 1987; Sengupta et al., 2015). MIPS and IMP genes were also shown to be

471 upregulated at low temperatures in plants like rice (Oryza sativa), yellow passion fruit (Passiflora

472 ligularis), or chickpea (Cicer arietinum) and have been implicated to play a role in environmental 
473 stress responses by promoting RFO biosynthesis (Abreu and Aragão, 2007; Kaur et al., 2008; Saxena

474 et al., 2013; R.-X. Zhang et al., 2017).

475 We observed that raffinose synthesis was highly upregulated upon freezing temperatures (Fig. 5 and

476 Table 1) suggesting a central role for the involved enzymes in sugar beet freezing response. Among

477 the four genes coding for GOLS isoforms in the sugar beet genome (Table1 and Supplemental

478 Figure S5), three were upregulated upon exposure to freezing, including the two closest homologs to

479 GOLS2 and GOLS3 from Arabidopsis. (Table 1 and Supplemental Figure S4). AtGOLS2 and AtGOLS3

480 are both known to be upregulated specifically by drought and cold stress (Maruyama et al., 2009;

481 Shen et al., 2020; Taji et al., 2002) and their induction involves DREB1A/CBF3 transcription factors

482 (Maruyama et al., 2009). These transcription factors are induced during exposure to low

483 temperatures (Gilmour et al., 1998; Shinwari et al., 1998; Fig. 2H), and their expression has been

484 shown to confer freezing tolerance in Arabidopsis, rice, or perennial ryegrass (Lolium perenne)

485 (Gilmour et al., 2000; Ito et al., 2006; Li et al., 2011).

486 Seven raffinose synthase isoforms were identified in sugar beet, of which two were not differentially

487 regulated upon exposure to low temperatures and three isoforms were differentially regulated in leaf

488 and taproot tissues (Table1 and Supplemental Figure S4). The two close homologs of AtRS2 and

489 AtRS5 were upregulated at freezing temperatures and showed the most pronounced induction in the

490 freezing tolerant cultivars GT2 and GT3 (Table 1). While AtRS2 was shown to possess $\alpha$-galactosidase

491 activity (Peters et al., 2010), AtRS5 was proven to be a raffinose synthase, upregulated in the cold

492 (Egert et al., 2013). Interestingly, BvRS5, the closest homolog to AtRS5, was also highly upregulated

493 in the piths of the two cultivars with higher freezing tolerance, GT2 and GT3, but not in freezing-

494 sensitive GT1 plants (Fig. 6B).

495 Upregulation of MIPS, IMP, GOLS and RS isoforms went along with high accumulation of inositol, 496 galactinol and raffinose upon exposure to freezing temperatures (Fig. 4). Interestingly, raffinose 
497 levels in the pith of more cold tolerant genotypes differed from concentrations in the pith of the

498 susceptible genotype - even in the absence of cold (Fig. 4D). GT2, the cultivar with the highest

499 freezing tolerance (Fig. 1A) and also the highest upregulation of several GOLS and RS isoforms (Table

500 1) shows the highest raffinose amounts in the pith region amongst the three genotypes, already at

$50120^{\circ} \mathrm{C}$. In GT3, increase in raffinose concentration upon subzero temperatures is highest, most likely

502 mediated by the high upregulation of RS5 specifically in the pith tissue (Fig. 6B and Fig. 4D). In GT1,

503 raffinose concentrations were not altered by freezing temperatures, which is in line with the

504 expression of raffinose synthases, which were not induced in the pith (Fig. 6B and Fig. 4D). These

505 data suggest that survival of the pith tissue might be linked to high raffinose concentrations and are

506 in line with previous reports, that showed that raffinose levels were elevated upon cold and freezing

507 temperatures (Koehler et al., 2015; Yue et al., 2015). Such conditions induce the formation of reactive

508 oxygen species (Gechev et al., 2006), which, when accumulating to high levels, can be harmful to the

509 plant, as they can damage membranes (lipid peroxidation), proteins, RNA and DNA molecules

510 (Choudhury et al., 2017). Accumulation of galactinol and raffinose on the other hand, can diminish

511 those harmful effects of ROS. This is because, high levels of these metabolites were shown to stabilize

512 ascorbate and glutathione concentrations, which are involved in detoxification of ROS concentrations

513 (Keller et al., 2021; Nishizawa-Yokoi et al., 2008). Furthermore, galactinol and raffinose show second-

514 order rate constants for detoxification of hydroxyl radicals higher than those of common antioxidants

515 like ascorbate or glutathione (Nishizawa-Yokoi et al., 2008). Although raffinose is synthesized in the

516 cytosol, about $20 \%$ of cellular raffinose is located to the chloroplasts and its concentration in plastids

517 is increased even further at low temperatures (Knaupp et al., 2011; Schneider and Keller, 2009). The

518 majority of cellular raffinose is, however, located in the vacuole, reaching about $60 \%$ in cold

519 acclimated Arabidopsis plants (Knaupp et al., 2011). In comparison to leaf tissue, taproot tissue does

520 hardly contain any chloroplasts and the vacuole is most likely the major place for raffinose

521 accumulation under low temperatures. There, raffinose might accumulate near the tonoplast together 
522 with other carbohydrates. Excess cytosolic $\mathrm{H}_{2} \mathrm{O}_{2}$ that passes through the tonoplast, or $\mathrm{H}_{2} \mathrm{O}_{2}$

523 originating from superoxide produced by tonoplast-localized NADPH oxidases, could then react with

524 raffinose, similar to the reaction proposed for fructans (Matros et al., 2015; Peshev et al., 2013), to

525 protect the tonoplast from membrane damage via ROS. In addition to its important role in ROS

526 detoxification, RFOs can assist in the osmotic adjustment and thereby maintain cell turgor during

527 water loss due to freezing (ElSayed et al., 2014) and protect the cell against severe damage. The higher

528 raffinose concentrations of the freezing tolerant cultivars GT2 and GT3 in comparison to freezing

529 sensitive GT1, especially in the freezing damage prone pith tissue, hint towards a beneficial

530 contribution of raffinose for freezing protection of this delicate tissue.

531 In Arabidopsis, ICE-CBF/DREB1-regulation is the main low temperature-responsive pathway leading

532 to raffinose accumulation (Janmohammadi et al., 2015) and in our experiments sugar beet CBF3 was

533 highly expressed at freezing temperature in the pith (Fig. 2H). It is tempting to speculate that the

534 regulation of the same pathway might cause an upregulation of specific GOLS and RS isoforms also

535 here in B. vulgaris, as the closest sugar beet homologs to AtGOLS2, AtGOLS3 and AtRS5 all show

536 similarly high upregulation upon freezing temperatures (Table 1, Supplemental Figure S4). This

537 suggests that accumulation of galactinol and especially of raffinose is a regulated acclimation reaction

538 of sugar beet plants rather than a result of an altered metabolism in the context of a general stress

539 response.

\section{MATERIAL AND METHODS}

\section{$541 \quad$ Plant Material and Growth conditions}

542 Three hybrid sugar beet genotypes with contrasting winter-hardiness (GT1, GT2, GT3; KWS SAAT SE,

543 Germany) were used. Plants were germinated and grown on standard soil substrate ED73

544 (Einheitserdwerke Patzer, Germany) with 10\% (v/v) sand under a $10 \mathrm{~h} \mathrm{light/14}$ h dark cycle, 60\% 
545 relative humidity, and $110 \mu \mathrm{mol} \mathrm{m} \mathrm{m}^{-2} \mathrm{~s}^{-1}$ light intensity. Plants were grown at $20^{\circ} \mathrm{C}$ for 10 weeks. The 546 plant population was split and one group was transferred to $12^{\circ} \mathrm{C}$ for one week and $4^{\circ} \mathrm{C}$ for one to two

547 weeks (one week for ROS and Photosynthesis measurements; two weeks for metabolite 548 measurements and gene expression) afterwards. After $4^{\circ} \mathrm{C}$ treatment, plants were transferred to $-6^{\circ} \mathrm{C}$

549 air temperature and were kept there until soil temperature reached $0^{\circ} \mathrm{C}$, which took approximately 550 three days (Figure 1B). Control plants were kept at $20^{\circ} \mathrm{C}$. During harvest, plants were dissected into 551 leaf, pith and storage root tissues, using a kitchen knife. The pith tissue was identified visually from

552 beets halved lengthwise by its peculiar cellular morphology (Figure 1E and Figure 2) by eye. Tissue 553 from two different plants was pooled and treated as one independent replicate, with a total of four 554 replicates per genotype and condition, respectively. After harvest, plant material was transferred to 555 liquid nitrogen. Samples used for metabolite analysis were lyophilized in an Alpha 2-4 LD plus freeze556 drier (Christ, Osterode am Harz, Germany) for seven days. Sampled material was pulverized using the 557 Retsch MM301 mill (Retsch, Haan, Germany) with a frequency of $30 \mathrm{~s}^{-1}$ for 30 seconds.

\section{Survival rate testing}

559 For survival rate testing of different sugar beet genotypes, greenhouse and field experiments were 560 carried out. Therefore, plants were sown out approximately three months before start of the frost 561 period. During experiments it was made sure, that plants were subjected to soil temperatures below $5620^{\circ} \mathrm{C}$. At least two weeks after frost treatment, dead or rotten sugar beets plants were counted and 563 survival rate was calculated. The survival rates monitor mean values of at least two replications in 564 independent years and at different locations.

\section{Chlorophyll Fluorescence Measurements}

566 Photosynthetic activity of three individual plants per genotype was measured using an Imaging-PAM 567 M-Series-System (Heinz Walz, Effeltrich, Germany). Plants were placed in the dark for 8 min to deplete 
568 the energy of PSII. Capacity of PSII was measured by saturation with 14 cycles of photosynthetically

569 active radiation $\left(76 \mu \mathrm{mol}\right.$ photons $\left.\mathrm{m}^{-2} \mathrm{~s}^{-1}\right)$ light-pulses at 0,50 , and $70 \mathrm{~s}$. Recorded fluorescence was

570 used for calculation of effective quantum yield of PSII (Y(II)) and quantum yield of nonphotochemical

571 quenching (Y(NPQ)).

\section{RNASeq analysis}

573 For RNASeq analysis plants were grown according to the growth regime mentioned by Martins

574 Rodrigues et al. 2020. Additionally, RNA extraction and analysis of RNASeq results including

575 statistical analysis was performed as described in Martins Rodrigues et al., 2020 and data was made

576 publicly available as BioProject PRJNA602804. For general overview of RNASeq results annotations

577 were assigned to the corresponding MapMan bincode found in the mapping file named

578 "Ath_AFFY_STv1.1_TRANSCRIPT_CLUSTER_TAIR10_LOCUS". Means over the log2FC over the three

579 independent genotypes were calculated for each bincode for leaf and taproot tissue, containing every

$580 \log 2 \mathrm{FC} \neq 0$ and without filtering for significant changes.

\section{Expression analysis via RT-qPCR}

582 Expression analysis of selected genes was performed by reverse transcription quantitative PCR (RT-

583 qPCR) using the primers listed in Supplemental Table S2. RNA was extracted from homogenized

584 sugar beet tissue using the NucleoSpin(R) RNA Plant Kit (Machery-Nagel, Düren, Germany) according

585 to the manufacturer's guidelines. RNA transcription into cDNA was performed using the qScript cDNA

586 Synthesis Kit (Quantbio, Beverly, USA).

\section{Metabolite extraction}

588 Soluble metabolites were extracted from freeze dried material. Pulverized material was extracted

589 twice $80 \% \mathrm{EtOH}$ at $80^{\circ} \mathrm{C}$ for $1 \mathrm{~h}$ while shaking. Metabolite extracts were combined and vaporized in a 
590 vacufuge concentrator (Eppendorf, Hamburg, Germany). Evaporated pellets were resolved in ${ }_{\mathrm{dd}} \mathrm{H}_{2} \mathrm{O}$.

591 Pellets remaining from extraction were washed with $80 \%$ EtOH and ${ }_{\mathrm{dd}} \mathrm{H}_{2} \mathrm{O}$ for starch isolation. $200 \mu \mathrm{l}$

$592 \mathrm{dd}_{2} \mathrm{O}$ were added to the pellet and samples were autoclaved for $40 \mathrm{~min}$ at $121^{\circ} \mathrm{C}$. For hydrolytic

593 cleavage $200 \mu$ l enzyme mix (5 U $\alpha$-Amylase; 5 U Amyloglucosidase; 200 mM Sodium-Acetate; pH 4.8)

594 were added to the pellet and incubated at $37^{\circ} \mathrm{C}$ for four hours. Enzymatic digestion was terminated

595 by heating to $95^{\circ} \mathrm{C}$ for 10 minutes. After centrifugation the supernatant was used for starch 596 quantification.

\section{Sugar and starch quantification}

598 Sugars (glucose, fructose, sucrose) and hydrolyzed starch concentrations were measured using a $599 \quad \mathrm{NAD}^{+}$-coupled enzymatic assay as described by (Stitt et al., 1989).

\section{Ion chromatography measurements}

601 Anions, cations, organic acids, sugar alcohols, galactinol and raffinose were measured in a 761

602 Compact IC system (Metrohm, Herisau, Switzerland). For anion concentration measurements a

603 Metrosep A Supp 4-250/4.0 column and a Metrosep A Supp 4/5 Guard/4.0 guard column (both

604 Metrohm, Herisau, Switzerland) was used. $50 \mathrm{mM} \mathrm{H}_{2} \mathrm{SO}_{4}$ was used as anti-ion and 1,8 $\mathrm{mM} \mathrm{Na}_{2} \mathrm{CO}_{3}$

605 together with $1,7 \mathrm{mM} \mathrm{NaHCO}_{3}$ dissolved in ultrapure water were used as eluent for anion

606 measurement. For determination of cation concentrations, a Metrosep C4 150/4.0 column and a

607 Metrosep C4 Guard/4.0 guard column (both Metrohm, Herisau, Switzerland) were used. The eluent

608 consisted of $2 \mathrm{mM} \mathrm{HNO}_{3}$ and 1,6 mM dipicolinic acid dissolved in ultrapure water. Organic acids were

609 separated via the Metrosep organic acids 250/7.8 column, a Metrosep Organic Acids Guard/4.6 guard

610 column (both Metrohm, Herisau, Switzerland), with 0,25 $\mathrm{mM} \mathrm{H}_{2} \mathrm{SO}_{4}$ dissolved in ultrapure water used

611 as eluent and $10 \mathrm{mM} \mathrm{LiCl}$ as anti-ion. Sugar alcohol, raffinose and galactinol quantification was done

612 by ion chromatography on a Metrosep Carb $2-250 / 4.0$ column using an 871 IC compact device 
613 (Metrohm-Switzerland, Herisau, Switzerland) followed by amperometric quantification. $\mathrm{NaOH}(0.1$

614 M) with Sodium acetate $(10 \mathrm{mM})$ was used as the mobile phase. For peak analysis the corresponding

615 software Metrodata IC Net 2.3 SR5 by Metrohm (Herisau, Switzerland) was used.

\section{High-performance liquid chromatography measurements}

617 Amino acid concentrations were measured via high performance liquid chromatography in a Dionex

618 (Dionex Softron, Germering, Germany) system, consisting of a Dionex ASI-100 automated sample 619 injector, a Dionex P680 HPLC pump and a Dionex RF2000 fluorescence detector. An AminoPac® PA1 620 column (Dionex Softron, Germering, Germany) was used for separation of amino acids. 0.1 M NaAc, 7

$621 \mathrm{mM}$ Triethanolamine pH 5.2 was used as eluent. Samples were prepared for measurement by adding $62260 \mu \mathrm{l}$ boric acid buffer (0.2 M; pH 8.8) and $20 \mu \mathrm{l}$ 6-aminoquinolyl-N-hydroxysuccinimidyl carbamate 623 (3 mg dissolved in $1.5 \mathrm{ml}$ Acetonitrile). Samples were vortexed and incubated at $55^{\circ} \mathrm{C}$ for 10 minutes. 624 Peaks were analyzed using the Chromeleon software (Thermo Fisher Scientific, Waltham, 625 Massachusetts, USA).

\section{Histological staining, microscopy and determination of cell size}

627 Longitudinal- and cross-sections of sugar beet taproot tissue with a thickness of about $0.5 \mathrm{~mm}$ were 628 made with the help of a truffle slicer. Sections were analyzed using a Leica MZ 10 F Binocular (Leica 629 Microsystems, Wetzlar, Germany). For histological staining of cell walls, cross sections were stained 630 using a Fuchsine-Chryosidine-Astra Blue (FCA) staining solution (Morphisto, Frankfurt am Main, 631 Germany). Sections were incubated in staining solution for 5 minutes, washed with water and 632 staining was differentiated in $70 \%$ ethanol.

633 For tracking of Phloem unloading in the root tissue, CFDA (5(6)-Carboxyfluorescein diacetate) was

634 loaded onto source leaves as described by Mehdi et al., 2019. Briefly, the cuticle of the upper surface 635 of source leaves was gently scratched with smooth sand paper. CFDA was prepared freshly from stock 
636 (stock: $10 \mathrm{mg} \mathrm{ml}^{-1}$ in acetone), by 1:7 dilution (v/v) with $\mathrm{ddH}_{2} \mathrm{O}$ and was pipetted on the roughened

637 leaf surface, which was covered with transparent foil to prevent evaporation through the scratched

638 cuticula. CFDA is non-fluorescent, but membrane permeable before the ester bonds are cleaved to

639 yield the green fluorescent CF (carboxyfluorescein), which then is trapped within cells.

640 Approximately $24 \mathrm{~h}$ after loading to the leaves, cross sections of taproot / pith tissue were cut using a

641 vibratome (125 $\mu$ m thickness), or by hand, cell walls were (counter-) stained with propidium iodide

642 and signals detected upon excitation with $488 \mathrm{~nm}$ on a Leica SP5 confocal microscope. (Leica,

643 Weimar, Germany).

644 Mean sizes of pith- and storage parenchyma cells were measured with ImageJ (Rasband, 1997-2018)

645 using microscope pictures of sugar beet cross-sections. For determination of pith cell size, cells from

646 the middle of the pith were chosen. For each cell type, ten cells of typical appearance were measured

647 per section. Overall, seven cross-sections were analyzed for cell size determination.

648

649 ROS staining and Antioxidant measurements

$650 \quad \mathrm{H}_{2} \mathrm{O}_{2}$ and $\mathrm{O}_{2}$-were detected in longitudinal taproot sections according to (Fryer et al., 2002). Sections

651 were vacuum infiltrated with $5 \mathrm{mM}$ DAB-HCl, $\mathrm{pH} 3$, or $5 \mathrm{mM}$ NBT in $50 \mathrm{mM}$ potassium-Phosphate-

652 buffer, pH7.8, for 1 hour and incubated at $4^{\circ} \mathrm{C}$ overnight until pictures were taken the next day. Total

653 and reduced ascorbate concentrations were measured according to Gillespie and Ainsworth (2007).

654 Freshly harvested and pulverized material was dissolved in 6\% TCA and immediately used for

655 colorimetric detection of ascorbate at $525 \mathrm{~nm}$ after the reaction with $\alpha$ - $\alpha$-bipyridyl. Oxidized DHA

656 concentration was calculated by subtraction of the reduced ascorbate from the total ascorbate

657 concentration. Total and oxidized glutathione concentrations were measured by the glutathione

658 reductase mediated reduction of 5'5-Dithiobis (-2-Nitrobenzoic acid) (DTNB) at 412nm according to

659 (Queval and Noctor, 2007). Reduced glutathione concentration was calculated by subtraction of the

660 oxidized glutathione from the total glutathione concentration. 


\section{Phylogeny}

662

663 Phylogeny of GOLS and RS isoforms was calculated using the www.phylogeny.fr "one-click" mode

664 (Dereeper et al., 2008). For graphical representation, phylogeny analysis from the Phylogeny.fr 665 platform was loaded into FigTree v1.4.4.

\section{Figure preparation}

667

668 Violin plots were generated using BoxPlotR web page (Spitzer et al., 2014). Figures were prepared 669 using Microsoft Excel and Microsoft PowerPoint.

\section{Statistical analyses}

671 Statistical analysis was performed using Origin Version 2018b (OriginLab Corporation, Northampton,

672 MA, USA). PC analysis was performed using MetaboAnalyst 4.0 web server

673 https://www.metaboanalyst.ca/ (Chong and Xia, 2018). 
682 Supplemental Figure S1. NBT staining of sugar beet taproot sections and antioxidant level of storage

683 parenchyma for ROS detection.

684 Supplemental Table S1. Metabolite concentrations of sugar beet leaf, pith and storage parenchyma

685 tissue.

686 Supplemental Figure S2. Differences in metabolite profile changes between sugar beet tissues upon

687 a shift in growth temperature from $20^{\circ} \mathrm{C}$ to $0^{\circ} \mathrm{C}$.

688 Supplemental Figure S3. Concentrations of starch, glucose, fructose and sucrose in leaf, pith and 689 root tissue under control and freezing temperatures.

690 Supplemental Figure S4. Phylogeny of Beta vulgaris GOLS and RS isoforms.

691 Supplemental Table S2. Oligonucleotides used in this study.

\section{ACKNOWLEDGMENTS}

694 The authors would like to thank Sebastian Stein, Tim Seibel (University of Kaiserslautern), Wiebke

695 Rettberg, Wenke Rettberg and Joern Koch (KWS) for help and support withle sugar beet harvesting 696 and Regina Rhode, Maike Siegel, Ralf Pennther-Hager (University of Kaiserslautern) and Michaela 697 Brock (FAU Erlangen) for excellent technical assistance and plant growth.

700 The authors declare no conflict of interest. 


\section{REFERENCES}

702

703

704

705

706

707

708

709

710

711

712

713

714

715

716

717

718

719

720

721

722

723

724

725

726

727

728

729

730

731

732

733

734

735

736

737

738

739

740

741

742

743

744

745

746

747

748

Abo-Elwafa, S., Abdel-Rahim, H., Abou-Salama, A., and Teama, E. (2006) Sugar beet floral induction and fertility: Effect of vernalization and day-length extension. Sugar Tech. 8: 281-287.

Abreu, E.F., and Aragão, F.J. (2007) Isolation and characterization of a myo-inositol-1phosphate synthase gene from yellow passion fruit (Passiflora edulis f. flavicarpa) expressed during seed development and environmental stress. Annals of Botany. 99: 285-292.

Anchordoguy, T.J., Rudolph, A.S., Carpenter, J.F., and Crowe, J.H. (1987) Modes of interaction of cryoprotectants with membrane phospholipids during freezing. Cryobiology. 24: 324331.

Artschwager, E. (1926) Anatomy of the vegetative organs of the sugar beet. US Government Printing Office.

Barbier, H., Nalin, F., and Guern, J. (1982) Freezing injury in sugar beet root cells: Sucrose leakage and modifications of tonoplast properties. Plant Science Letters. 26: 75-81.

Bellin, D., Schulz, B., Soerensen, T.R., Salamini, F., and Schneider, K. (2007) Transcript profiles at different growth stages and tap-root zones identify correlated developmental and metabolic pathways of sugar beet. $J$ Exp Bot. 58.

Burke, M., Gusta, L., Quamme, H., Weiser, C., and Li, P. (1976) Freezing and injury in plants. Annual Review of Plant Physiology. 27: 507-528.

Chang, D.C., Sohn, H.B., Cho, J.H., Im, J.S., Jin, Y.I., Do, G.R., et al. (2014) Freezing and frost damage of potato plants: a case study on growth recovery, yield response, and quality changes. Potato Research. 57: 99-110.

Chen, T., Li, Z., Yin, X., Hu, F., and Hu, C. (2016) Discrimination of genetically modified sugar beets based on terahertz spectroscopy. Spectrochimica Acta Part A: Molecular and Biomolecular Spectroscopy. 153: 586-590.

Chong, J., and Xia, J. (2018) MetaboAnalystR: an R package for flexible and reproducible analysis of metabolomics data. Bioinformatics. 34: 4313-4314.

Choudhury, F.K., Rivero, R.M., Blumwald, E., and Mittler, R. (2017) Reactive oxygen species, abiotic stress and stress combination. The Plant Journal. 90: 856-867.

Cunningham, S., Nadeau, P., Castonguay, Y., Laberge, S., and Volenec, J. (2003) Raffinose and stachyose accumulation, galactinol synthase expression, and winter injury of contrasting alfalfa germplasms. Crop Science. 43: 562-570.

De Roover, J., Vandenbranden, K., Van Laere, A., and Van den Ende, W. (2000) Drought induces fructan synthesis and 1-SST (sucrose: sucrose fructosyltransferase) in roots and leaves of chicory seedlings (Cichorium intybus L.). Planta. 210: 808-814.

Dereeper, A., Guignon, V., Blanc, G., Audic, S., Buffet, S., Chevenet, F., et al. (2008) Phylogeny. fr: robust phylogenetic analysis for the non-specialist. Nucleic acids research. 36: W465-W469.

Dohm, J.C., Minoche, A.E., Holtgräwe, D., Capella-Gutiérrez, S., Zakrzewski, F., Tafer, H., et al. (2013) The genome of the recently domesticated crop plant sugar beet (Beta vulgaris). Nature. 505: 546.

Donahue, J.L., Alford, S.R., Torabinejad, J., Kerwin, R.E., Nourbakhsh, A., Ray, W.K., et al. (2010) The Arabidopsis thaliana myo-inositol 1-phosphate synthase1 gene is required for myo-inositol synthesis and suppression of cell death. The Plant Cell. 22: 888-903.

Egert, A., Keller, F., and Peters, S. (2013) Abiotic stress-induced accumulation of raffinose in Arabidopsis leaves is mediated by a single raffinose synthase (RS5, At5g40390). BMC Plant Biology. 13: 1-9. 
749

750

751

752

753

754

755

756

757

758

759

760

761

762

763

764

765

766

767

768

769

770

771

772

773

774

775

776

777

778

779

780

781

782

783

784

785

786

787

788

789

790

791

792

793

794

795

796

797

798

EISayed, A.I., Rafudeen, M.S., and Golldack, D. (2014) Physiological aspects of raffinose family oligosaccharides in plants: protection against abiotic stress. Plant Biology. 16: 1-8.

Fanucchi, F., Alpi, E., Olivieri, S., Cannistraci, C.V., Bachi, A., Alpi, A., et al. (2012) Acclimation increases freezing stress response of Arabidopsis thaliana at proteome level. Biochimica et Biophysica Acta (BBA)-Proteins and Proteomics. 1824: 813-825.

Fennell, A. (2004) Freezing tolerance and injury in grapevines. Journal of Crop Improvement. 10: 201-235.

Fowler, S., and Thomashow, M.F. (2002) Arabidopsis transcriptome profiling indicates that multiple regulatory pathways are activated during cold acclimation in addition to the CBF cold response pathway. The Plant Cell. 14: 1675-1690.

Fryer, M.J., Oxborough, K., Mullineaux, P.M., and Baker, N.R. (2002) Imaging of photo-oxidative stress responses in leaves. Journal of experimental botany. 53: 1249-1254.

Ganter, C., Böck, A., Buckel, P., and Mattes, R. (1988) Production of thermostable, recombinant $\alpha$-galactosidase suitable for raffinose elimination from sugar beet syrup. Journal of Biotechnology. 8: 301-310.

Gechev, T.S., Van Breusegem, F., Stone, J.M., Denev, I., and Laloi, C. (2006) Reactive oxygen species as signals that modulate plant stress responses and programmed cell death. Bioessays. 28: 1091-1101.

Giaquinta, R.T. (1979) Sucrose translocation and storage in the sugar beet. Plant Physiol. 63.

Gillespie, K.M., and Ainsworth, E.A. (2007) Measurement of reduced, oxidized and total ascorbate content in plants. Nature Protocols. 2: 871-874.

Gilmour, S.J., Sebolt, A.M., Salazar, M.P., Everard, J.D., and Thomashow, M.F. (2000) Overexpression of the Arabidopsis CBF3transcriptional activator mimics multiple biochemical changes associated with cold acclimation. Plant physiology. 124: 18541865.

Gilmour, S.J., Zarka, D.G., Stockinger, E.J., Salazar, M.P., Houghton, J.M., and Thomashow, M.F. (1998) Low temperature regulation of the Arabidopsis CBF family of AP2 transcriptional activators as an early step in cold-induced COR gene expression. The Plant Journal. 16: 433-442.

Guy, C.L. (1990) Cold acclimation and freezing stress tolerance: role of protein metabolism. Annual review of plant biology. 41: 187-223.

Haagenson, D.M., Klotz, K.L., and Campbell, L. (2008) Impact of storage temperature, storage duration, and harvest date on sugarbeet raffinose metabolism. Postharvest biology and technology. 49: 221-228.

Hincha, D.K., Livingston III, D.P., Premakumar, R., Zuther, E., Obel, N., Cacela, C., et al. (2007) Fructans from oat and rye: composition and effects on membrane stability during drying. Biochimica et Biophysica Acta (BBA)-Biomembranes. 1768: 1611-1619.

Ho, L.-H., Rode, R., Siegel, M., Reinhardt, F., Neuhaus, H.E., Yvin, J.-C., et al. (2020) Potassium Application Boosts Photosynthesis and Sorbitol Biosynthesis and Accelerates Cold Acclimation of Common Plantain (Plantago major L.). Plants. 9: 1259.

Hoffmann, C.M., and Kluge-Severin, S. (2011) Growth analysis of autumn and spring sown sugar beet. European Journal of Agronomy. 34: 1-9.

Ito, Y., Katsura, K., Maruyama, K., Taji, T., Kobayashi, M., Seki, M., et al. (2006) Functional analysis of rice DREB1/CBF-type transcription factors involved in cold-responsive gene expression in transgenic rice. Plant and Cell Physiology. 47: 141-153.

Jaggard, K., Qi, A., and Ober, E. (2009) Capture and use of solar radiation, water, and nitrogen by sugar beet (Beta vulgaris L.). Journal of experimental botany. 60: 1919-1925.

Jahnke, S., Menzel, M.I., Van Dusschoten, D., Roeb, G.W., Bühler, J., Minwuyelet, S., et al. (2009) Combined MRI-PET dissects dynamic changes in plant structures and functions. The Plant Journal. 59: 634-644. 
799

800

801

802

803

804

805

806

807

808

809

810

811

812

813

814

815

816

817

818

819

820

821

822

823

824

825

826

827

828

829

830

831

832

833

834

835

836

837

838

839

840

841

842

843

844

845

846

847

848

Janmohammadi, M., Zolla, L., and Rinalducci, S. (2015) Low temperature tolerance in plants: changes at the protein level. Phytochemistry. 117: 76-89.

Kaur, H., Shukla, R.K., Yadav, G., Chattopadhyay, D., and Majee, M. (2008) Two divergent genes encoding L-myo-inositol 1-phosphate synthase1 (CaMIPS1) and 2 (CaMIPS2) are differentially expressed in chickpea. Plant, Cell \& Environment. 31: 1701-1716.

Keller, I., Rodrigues, C.M., Neuhaus, H.E., and Pommerrenig, B. (2021) Improved resource allocation and stabilization of yield under abiotic stress. Journal of Plant Physiology. 257: 153336.

Klemens, P.A.W., Patzke, K., Trentmann, O., Poschet, G., Büttner, M., Schulz, A., et al. (2014) Overexpression of a proton-coupled vacuolar glucose exporter impairs freezing tolerance and seed germination. New Phytologist. 202: 188-197.

Knaupp, M., Mishra, K.B., Nedbal, L., and Heyer, A.G. (2011) Evidence for a role of raffinose in stabilizing photosystem Il during freeze-thaw cycles. Planta. 234: 477-486.

Knoblauch, M., Vendrell, M., de Leau, E., Paterlini, A., Knox, K., Ross-Elliot, T., et al. (2015) Multispectral Phloem-Mobile Probes: Properties and Applications. Plant Physiol. 167: 1211.

Kockelmann, A., Tilcher, R., and Fischer, U. (2010) Seed production and processing. Sugar Tech. 12: 267-275.

Koehler, G., Rohloff, J., Wilson, R.C., Kopka, J., Erban, A., Winge, P., et al. (2015) Integrative "omic" analysis reveals distinctive cold responses in leaves and roots of strawberry, Fragariax ananassa 'Korona'. Frontiers in plant science. 6: 826.

Li, T., Zhang, Y., Liu, Y., Li, X., Hao, G., Han, Q., et al. (2020) Raffinose synthase enhances drought tolerance through raffinose synthesis or galactinol hydrolysis in maize and Arabidopsis plants. Journal of Biological Chemistry. 295: 8064-8077.

Li, X., Cheng, X., Liu, J., Zeng, H., Han, L., and Tang, W. (2011) Heterologous expression of the Arabidopsis DREB1A/CBF3 gene enhances drought and freezing tolerance in transgenic Lolium perenne plants. Plant Biotechnology Reports. 5: 61-69.

Liu, Y., Dang, P., Liu, L., and He, C. (2019) Cold acclimation by the CBF-COR pathway in a changing climate: Lessons from Arabidopsis thaliana. Plant cell reports. 38: 511-519.

Loel, J., and Hoffmann, C. (2015) Relevance of osmotic and frost protecting compounds for the winter hardiness of autumn sown sugar beet. Journal of Agronomy and Crop Science. 201: 301-311.

Loewus, F.A., and Murthy, P.P. (2000) myo-Inositol metabolism in plants. Plant science. 150: 119.

Maqbool, A., Shafiq, S., and Lake, L. (2010) Radiant frost tolerance in pulse crops-a review. Euphytica. 172: 1-12.

Maruyama, K., Takeda, M., Kidokoro, S., Yamada, K., Sakuma, Y., Urano, K., et al. (2009) Metabolic pathways involved in cold acclimation identified by integrated analysis of metabolites and transcripts regulated by DREB1A and DREB2A. Plant physiology. 150: 1972-1980.

Matros, A., Peshev, D., Peukert, M., Mock, H., and Van den Ende, W. (2015) Sugars as hydroxyl radical scavengers: proof-of-concept by studying the fate of sucralose in Arabidopsis. The Plant Journal. 82: 822-839.

Mehdi, R., Lamm, C.E., Bodampalli Anjanappa, R., Müdsam, C., Saeed, M., Klima, J., et al. (2019) Symplasmic phloem unloading and radial post-phloem transport via vascular rays in tuberous roots of Manihot esculenta. Journal of experimental botany. 70: 5559-5573.

Metzner, R., van Dusschoten, D., Bühler, J., Schurr, U., and Jahnke, S. (2014) Belowground plant development measured with magnetic resonance imaging (MRI): exploiting the potential for non-invasive trait quantification using sugar beet as a proxy. Frontiers in plant science. 5: 469. 
849

850

851

852

853

854

855

856

857

858

859

860

861

862

863

864

865

866

867

868

869

870

871

872

873

874

875

876

877

878

879

880

881

882

883

884

885

886

887

888

889

890

891

892

893

894

895

896

897

898

Milford, G., and Riley, J. (1980) The effects of temperature on leaf growth of sugar beet varieties. Annals of Applied Biology. 94: 431-443.

Moliterni, V.M.C., Paris, R., Onofri, C., Orrù, L., Cattivelli, L., Pacifico, D., et al. (2015) Early transcriptional changes in Beta vulgaris in response to low temperature. Planta. 242: 187-201.

Nishizawa, A., Yabuta, Y., and Shigeoka, S. (2008) Galactinol and raffinose constitute a novel function to protect plants from oxidative damage. Plant physiology. 147: 1251-1263.

Nishizawa-Yokoi, A., Yabuta, Y., and Shigeoka, S. (2008) The contribution of carbohydrates including raffinose family oligosaccharides and sugar alcohols to protection of plant cells from oxidative damage. Plant signaling \& behavior. 3: 1016-1018.

Pennycooke, J.C., Jones, M.L., and Stushnoff, C. (2003) Down-regulating a-galactosidase enhances freezing tolerance in transgenic petunia. Plant Physiology. 133: 901-909.

Peshev, D., Vergauwen, R., Moglia, A., Hideg, É., and Van den Ende, W. (2013) Towards understanding vacuolar antioxidant mechanisms: a role for fructans? Journal of Experimental Botany. 64: 1025-1038.

Peters, S., Egert, A., Stieger, B., and Keller, F. (2010) Functional identification of Arabidopsis ATSIP2 (At3g57520) as an alkaline $\alpha$-galactosidase with a substrate specificity for raffinose and an apparent sink-specific expression pattern. Plant and cell physiology. 51: 1815-1819.

Peters, S., and Keller, F. (2009) Frost tolerance in excised leaves of the common bugle (Ajuga reptans $L$.) correlates positively with the concentrations of raffinose family oligosaccharides (RFOs). Plant, Cell \& Environment. 32: 1099-1107.

Pommerrenig, B., Cvetkovic, J., Trentmann, O., Klemens, P.A.W., Neuhaus, H.E., and Ludewig, F. (2018) In Concert: Orchestrated Changes in Carbohydrate Homeostasis Are Critical for Plant Abiotic Stress Tolerance. Plant and Cell Physiology. 59: 1290-1299.

Pommerrenig, B., Müdsam, C., Kischka, D., and Neuhaus, H.E. (2020) Treat and Trick: Common Regulation and Manipulation of Sugar Transporters During Sink Establishment by the Plant and the Invader. Journal of Experimental Botany.

Pontis, H. (1989) Fructans and cold stress. Journal of Plant Physiology. 134: 148-150.

Queval, G., and Noctor, G. (2007) A plate reader method for the measurement of NAD, NADP, glutathione, and ascorbate in tissue extracts: application to redox profiling during Arabidopsis rosette development. Analytical biochemistry. 363: 58-69.

Rodrigues, C.M., Müdsam, C., Keller, I., Zierer, W., Czarnecki, O., Corral, J.M., et al. (2020) Vernalization Alters Sink and Source Identities and Reverses Phloem Translocation from Taproots to Shoots in Sugar Beet (Beta vulgaris). The Plant Cell.

Saito, M., and Yoshida, M. (2011) Expression analysis of the gene family associated with raffinose accumulation in rice seedlings under cold stress. Journal of plant physiology. 168: 2268-2271.

Saravitz, D.M., Pharr, D.M., and Carter, T.E. (1987) Galactinol synthase activity and soluble sugars in developing seeds of four soybean genotypes. Plant physiology. 83: 185-189.

Saxena, S.C., Salvi, P., Kaur, H., Verma, P., Petla, B.P., Rao, V., et al. (2013) Differentially expressed myo-inositol monophosphatase gene (CalMP) in chickpea (Cicer arietinum L.) encodes a lithium-sensitive phosphatase enzyme with broad substrate specificity and improves seed germination and seedling growth under abiotic stresses. Journal of experimental botany. 64: 5623-5639.

Schneider, T., and Keller, F. (2009) Raffinose in chloroplasts is synthesized in the cytosol and transported across the chloroplast envelope. Plant and Cell Physiology. 50: 2174-2182.

Sengupta, S., Mukherjee, S., Basak, P., and Majumder, A.L. (2015) Significance of galactinol and raffinose family oligosaccharide synthesis in plants. Frontiers in plant science. 6 : 656. 
899

900

901

902

903

904

905

906

907

908

909

910

911

912

913

914

915

916

917

918

919

920

921

922

923

924

925

926

927

928

929

930

931

932

933

934

935

936

937

938

939

940

941

942

943

944

945

946

947

948

Shen, Y., Jia, B., Wang, J., Cai, X., Hu, B., Wang, Y., et al. (2020) Functional analysis of Arabidopsis thaliana galactinol synthase AtGolS2 in response to abiotic stress. Molecular Plant Breeding. 11.

Shinwari, Z.K., Nakashima, K., Miura, S., Kasuga, M., Seki, M., Yamaguchi-Shinozaki, K., et al. (1998) An Arabidopsis gene family encoding DRE/CRT binding proteins involved in lowtemperature-responsive gene expression. Biochemical and biophysical research communications. 250: 161-170.

Spitzer, M., Wildenhain, J., Rappsilber, J., and Tyers, M. (2014) BoxPlotR: a web tool for generation of box plots. Nature methods. 11: 121.

Sprenger, N., and Keller, F. (2000) Allocation of raffinose family oligosaccharides to transport and storage pools in Ajuga reptans: the roles of two distinct galactinol synthases. The Plant Journal. 21: 249-258.

Stitt, M., Lilley, R.McC., Gerhardt, R., and Heldt, H.W. (1989) [32] Metabolite levels in specific cells and subcellular compartments of plant leaves. In Methods in Enzymology. pp. 518552 Academic Press.

Strand, A.., Hurry, V., Gustafsson, P., and Gardeström, P. (1997) Development of Arabidopsis thaliana leaves at low temperatures releases the suppression of photosynthesis and photosynthetic gene expression despite the accumulation of soluble carbohydrates. The Plant Journal. 12: 605-614.

Taji, T., Ohsumi, C., luchi, S., Seki, M., Kasuga, M., Kobayashi, M., et al. (2002) Important roles of drought-and cold-inducible genes for galactinol synthase in stress tolerance in Arabidopsis thaliana. The Plant Journal. 29: 417-426.

Thomashow, M.F. (1999) Plant cold acclimation: freezing tolerance genes and regulatory mechanisms. Annual review of plant biology. 50: 571-599.

Turesson, H., Andersson, M., Marttila, S., Thulin, I., and Hofvander, P. (2014) Starch biosynthetic genes and enzymes are expressed and active in the absence of starch accumulation in sugar beet tap-root. BMC Plant Biology. 14: 104.

Usadel, B., Blaesing, O.E., Gibon, Y., Poree, F., Hoehne, M., Guenter, M., et al. (2008) Multilevel genomic analysis of the response of transcripts, enzyme activities and metabolites in Arabidopsis rosettes to a progressive decrease of temperature in the nonfreezing range. Plant, Cell \& Environment. 31: 518-547.

Wolfe, J., and Bryant, G. (1999) Freezing, Drying, and/or Vitrification of Membrane- SoluteWater Systems. Cryobiology. 39: 103-129.

Wyse, R., and Dexter, S. (1971) Effect of agronomic and storage practices on raffinose, reducing sugar, and amino acid content of sugarbeet varieties. J Am Soc Sugar Beet Technol. 16: 369-383.

Yadav, S.K. (2010) Cold stress tolerance mechanisms in plants. A review. Agronomy for sustainable development. 30: 515-527.

Yue, C., Cao, H.-L., Wang, L., Zhou, Y.-H., Huang, Y.-T., Hao, X.-Y., et al. (2015) Effects of cold acclimation on sugar metabolism and sugar-related gene expression in tea plant during the winter season. Plant molecular biology. 88: 591-608.

Zhang, R.-X., Qin, L.-J., and Zhao, D.-G. (2017) Overexpression of the OsIMP gene increases the accumulation of inositol and confers enhanced cold tolerance in tobacco through modulation of the antioxidant enzymes' activities. Genes. 8: 179.

Zhang, Y.-F., Li, G.-L., Wang, X.-F., Sun, Y.-Q., and Zhang, S.-Y. (2017) Transcriptomic profiling of taproot growth and sucrose accumulation in sugar beet (Beta vulgaris L.) at different developmental stages. PloS one. 12: e0175454.

Zhuo, C., Wang, T., Lu, S., Zhao, Y., Li, X., and Guo, Z. (2013) A cold responsive galactinol synthase gene from Medicago falcata (MfGolS1) is induced by myo-inositol and confers multiple tolerances to abiotic stresses. Physiologia plantarum. 149: 67-78. 
bioRxiv preprint doi: https://doi.org/10.1101/2021.04.12.439442; this version posted April 13, 2021. The copyright holder for this preprint (which

was not certified by peer review) is the author/funder, who has granted bioRxiv a license to display the preprint in perpetuity. It is made available under aCC-BY-NC-ND 4.0 International license.

949 Zuther, E., Büchel, K., Hundertmark, M., Stitt, M., Hincha, D.K., and Heyer, A.G. (2004) The role of raffinose in the cold acclimation response of Arabidopsis thaliana. Febs Letters. 576: 169-173. 